\title{
Landscape Construction and Long-Term Economic Practices: an Example from the Spanish Mediterranean Uplands Through Rock Art Archaeology
}

\author{
María Cruz Berrocal • María Sebastián López • \\ Antonio Uriarte González • \\ Jose Antonio López-Sáez
}

\begin{abstract}
We argue in this paper that Levantine rock art in the Spanish Mediterranean basin allows us to 'map' the economic landscape of its makers. Rock art would be the 'monumental' side of a dual process of landscape construction: on the one hand, rock art is the first 'cultural' action on the landscape beginning in the Early Neolithic; on the other hand, the first evidence of active modification of the Mediterranean vegetation comes from this period. But this evidence as well as other kinds of archaeological remains are still relatively scarce in the uplands; rock art is therefore the most complete type of evidence we can use to support an early use of the Mediterranean upland environment. We use statistical and geographical analysis, together with archaeological, ethnohistorical, and ethnographic sources and pollen data, in order to support the idea of early use and exploitation of the Mediterranean uplands since the Neolithic, and into contemporary times.
\end{abstract}

Keywords Mediterranean landscape $\cdot$ Neolithic $\cdot$ Rock art $\cdot$ Economic resources

\section{Introduction}

This paper argues that Levantine rock art is the first visible sign of the existence of economic practices specifically adapted to the potential land use associated with the uplands of the Spanish Mediterranean basin. These economic practices took full shape during the Early Neolithic (Bernabeu et al. 1993) and are in place until contemporary times (see below). The existence of rock art, and its location in very specifically selected places in the landscape, intimately associated with a particular landscape structure, are the main supports of this proposal. It is precisely the land use

M. Cruz Berrocal $(\bowtie) \cdot$ M. Sebastián López $\cdot$ A. Uriarte González $\cdot$ J. A. López-Sáez Institute of History, Center for the Social Sciences and Humanities (CCHS),

High Council for Scientific Research (CSIC), c/ Albasanz 26-28, Madrid 28037, Spain

e-mail: maria.berrocal@cchs.csic.es 
associated with rock art from the beginning of farming and agriculture which has actually built the Mediterranean upland landscape as we know it, and it is precisely the abandonment of these economic activities the main cause of its decay and in some cases its destruction.

The Mediterranean uplands are middle-altitude mountainous ranges, where 'typical Mediterranean' (e.g., Hobbs et al. 1995, p. 17) derivative vegetation formations (maquía and garrigue) prone to fire (Riera 1996; Walsh 1999; Riera et al. 2004; Carrión et al. 2007) coexist with derivative forests. It is generally accepted that the Mediterranean upland areas of the Iberian Peninsula have remained fairly stable along time, or more accurately, resilient: they have kept the "ability to resist or accommodate external pressures without seriously transforming itself" (Redman et al. 2004, p. 3 ), due to the modification of the environment caused by extensive exploitative practices at the broad regional scale; changing conditions at the local level did not necessarily change the basic long-term regional picture (Aura et al. 1998; Carrión 2002; Gil-Romera et al. 2010).

A reliable proof of this resilient character is to be found in rock art: Levantine rock art sites have been used from the Early Neolithic to the twentieth century most likely due to their sheltering capacity and their relationship with specific resources in their surroundings, thus keeping a very relevant role throughout history as part of a system of risk buffering of the farming economy in the Iberian Peninsula, especially significant in the Mediterranean facade. Thus, although rock art is often thought of as a means of access into the cognitive, religious, and cultural realms of a social formation, we will rather argue that rock art can help us understand the long-term rythms of landscapes-its construction processes and its use along time. In short, we observe rock art as a very relevant kind of archaeological evidence for the understanding of landscapes, mainly because it allows us to observe a territory as a meaningful cultural or social spatial entity. Otherwise it would be easy to only see a compound of fragmentary spaces.

Palaeoenvironmental, geomorphological, archaeological, and ethnographic and ethnohistoric records are of course relevant for this study; lacunae in their data sets are however still important. It seems that lack of information has been widespread in the archaeology of mountainous areas and the study of long-term land use and landscape structures in the uplands. As Barker and Bintliff (1999, p. 209) put it, there is a general "lack of emphasis on investigating the prehistory and history of Mediterranean uplands". Being rock art one of the few material types of evidence of human use of the uplands since very early times, it is odd that its potential has not been strongly emphasized before, as this paper does.

Legitimate concerns that “...modern or early modern ethnohistoric parallels are merely a source of models, not a blueprint for claiming, for example, a continuity of land use and mode de vie in a given regional landscape" (Barker and Bintliff 1999, p. 207) have been raised; certainly, while there may be a basic continuity in land use due to suitable environmental conditions, political forms and ways of life may differ radically. Economic exploitative practices may remain basically unaltered, but their significance varies according to regional and interregional social, political, and economic dynamics. In the Mediterranean basin, pastoral, agricultural, and forestry resources have been shaped and used in the same ways for millennia (Lasanta 1987); yet their historical contexts and institutional matrices have differed. A focus on silvopastoral land use does not imply that the access to resources, the organization 
of labor, and, in general, the social relations enabling these economic practices, remained the same throughout the ages. In fact, we know that this was not the case. Ways of life can retain basic features while larger social structures and political forms change. Thus, in this paper, we argue for continuity, not for statism.

A further reflection applies here. As we propose in this paper, the Mediterranean landscape is the corollary of at least seven millennia of human work. In the context of a scenario of inertia and resilience at a palaeoecological scale (Carrión 2002; Carrión et al. 2007; Gil-Romera et al. 2010), with fundamental continuity and slow, gradual and cumulative pace of change (Butzer 2005; Shiel 1999) along millennia, human activity plays a big role, both in Eastern and Western Mediterranean (Horden and Purcell 2000; van der Leeuw and de Vries 2002; Butzer 2005; Berger et al. 2007). ${ }^{1}$ This brings us to the notion of 'working landscape' (Diekmann et al. 2007) to describe the Mediterranean uplands: a cumulative enterprise, a historical scenario basically contingent and dialectic in nature, the product of long-term co-evolutionary processes (Davis and Rutherford 1995; Naveh 1998) of human-environment dependence (or 'a system in non-equilibrium', see Naveh 1998). Mediterranean resilience is a product of the dependence between human labor and 'nature', so much so that the ability of the Mediterranean landscape to stay resilient is totally entrenched in the investment of social work (van der Leeuw and de Vries 2002; Butzer 2005; GilRomera et al. 2010). ${ }^{2}$ Ways of life, meaning ways of work, do produce and sustain particular 'working landscapes'. It follows that real environmental degradation is a function of sociopolitical disturbance or change (e.g., Butzer 2005), as it produces a stop or forces a shift in the invested work. This is what happened in the last decades in the Spanish Mediterranean basin, especially in the lowlands: a dramatic change in land use, a likely important factor in its degradation (e.g., Hobbs et al. 1995; Naveh 1998; Rundel 1998; Butzer 2005; González-Hidalgo et al. 2007; García-Ruiz 2010). In the uplands, work has traditionally been less work intensive and therefore the risks produced by abandonment are also less pressing, but traditional ways of life fade away generation after generation (Creighton and Seguí 1998; Christie et al. 2007). An ecologically fine-tuned Mediterranean environment (Butzer 1996) is increasingly under siege, and prospects for future management and preservation are doomed to fail as long as they are not accompanied by policies that keep people living and working the landscape. In our view, studies that emphasize the long-term nature of the Mediterranean uplands should be relevant in order to understand the scope of the problem.

\footnotetext{
${ }^{1}$ The history of the Mediterranean landscape is, to some extent, a history of erosive processes and soil loss, and the determination of their climatic vs. anthropic origin. The debate 'Younger Fill' (Vita-Finzi 1969) vs. non-synchronic accumulations of human-induced episodes of soil erosion (e.g. van Andel et al. 1990; Walsh 1999; Horden and Purcell 2000)_-see Bintliff (2002) for a review_was a significant landmark in this regard. After the Neolithic, however, it is difficult to isolate climatic events as triggers of global cultural changes in the Mediterranean (Jalut et al. 1997; Carrión et al. 2000), and emphasis is increasingly put on the interplay of decision-making humans and their environment (e.g. Davis and Richardson 1995; Rundel et al. 1998; Naveh 1998; Horden and Purcell 2000; van der Leeuw and de Vries 2002; Butzer 2005).

${ }^{2}$ Co-evolution has created its own dynamics of risk, crisis and threats. It has been proposed (Horden and Purcell 2000; van der Leeuw and de Vries 2002; de Vries et al. 2002) that the additive and reiterative human work and modification of the landscape led to the replacement of short-term risks, such as seasonal floods, by long-term risks, triggering unpredictable instability on the long term.
} 
We will present first the current pollen evidence pointing to a vegetation modification starting in the Neolithic. Next, we will present our interpretation of the archaeological record as observed in the Levantine rock art, with input from the ethnohistorical and ethnographic record.

\section{Palaeoenvironmental Context}

The existing pollen records, anthracological analyses and geomorphological data point to anthropogenic modification of the vegetation in different parts of the Western Mediterranean beginning with the Neolithic, as well as changes produced by shifting climatic conditions (Dupré 1988; Badal et al. 1994; Badal and Roiron 1995; Carrión and van Geel 1999; López-Sáez and López-García 1999; Sánchez-Goñi and Hannon 1999; López-García and López-Sáez 2000; Carrión et al. 2001a, b; Carrión 2002; Riera et al. 2004; López-Sáez et al. 2006, 2011, González-Sampériz et al. 2006, 2008). In the Spanish Mediterranean basin, several cycles of vegetation replacement or loss have been observed on lowlands and upland areas, although response times cannot be measured, and it remains open to debate how the combination of climate with human impact is ultimately responsible for the observed rapid shifts in vegetation (Jalut et al. 2000; Carrión 2001a; Carrión et al. 2010).

In the last decades, an important effort has been made in Spain to study nonarchaeological pollen sequences in the uplands (e.g., Carrión 2001b, c, 2002; Carrión et al. 2001a, 2004, 2007, 2010) that complete the pollen sequences obtained from archaeological sites or natural deposits located in the lowlands (e.g., López-Sáez et al. 2003, 2011). Despite an important debate over the natural or anthropic role of fire in the modification of the vegetation cover (Davis 1994; López-García and López-Sáez 2000; Stevenson 2000; Carrión et al. 2001a, b; González-Sampériz 2004) in the Mediterranean basin, and some data voids, a general picture can now be presented (Fig. 1).

In the Catalan Pyrenees the first evidence of anthropic modification is placed between ca. 7,000 and 6,000 cal BP (e.g., Montserrat and Vilaplana 1987; Gómez and Esteban 1993; Pèlachs et al. 2007; Pérez-Obiol et al. 2012). The pollen sequence from the Estanilles peat bog (2,247 m.a.s.l.), for instance, shows a clear episode of open land vegetation during the Neolithic, starting at ca. 7,000 cal BP. It is related to the use of fire and signals of soil erosion, as well as to indicators of pollen of anthropic origin (Pérez-Obiol et al. 2012). In the Andorran eastern Pyrenees (Perafita and Madriu valleys), the pollen data (sequences from Planells de Perafita, Bosc dels Estanyons, and Riu dels Orris; 2,150, 2,180, and 2,390 m.a.s.1., respectively) suggest human presence in the sub-alpine belt as early as the late Mesolithic-Early Neolithic transition (ca. 8,350-7,700 cal BP). This presence was likely of a seasonal nature, but the vegetation appears to be strongly influenced by human activities (agriculture and grazing) only at the end of the early Neolithic, ca. 7,250-6,850 cal BP (Miras et al. 2007, 2010; Ejarque et al. 2010).

In the Aragón Pyrenees, this anthropic impact is delayed until the fifth millenium cal BP (Montserrat 1992), although some intriguing data remain. Early Neolithic pollen evidence coming from Chaves cave, dated to $6,770 \pm 70(7,750-7,495 \mathrm{cal})$, $6,650 \pm 80(7,660-7,425 \mathrm{cal})$ and $6,460 \pm 70(7,500-7,255 \mathrm{cal}) \mathrm{BP}$, show human active modification of the vegetation through fire, plausibly interpreted as an aim to open 


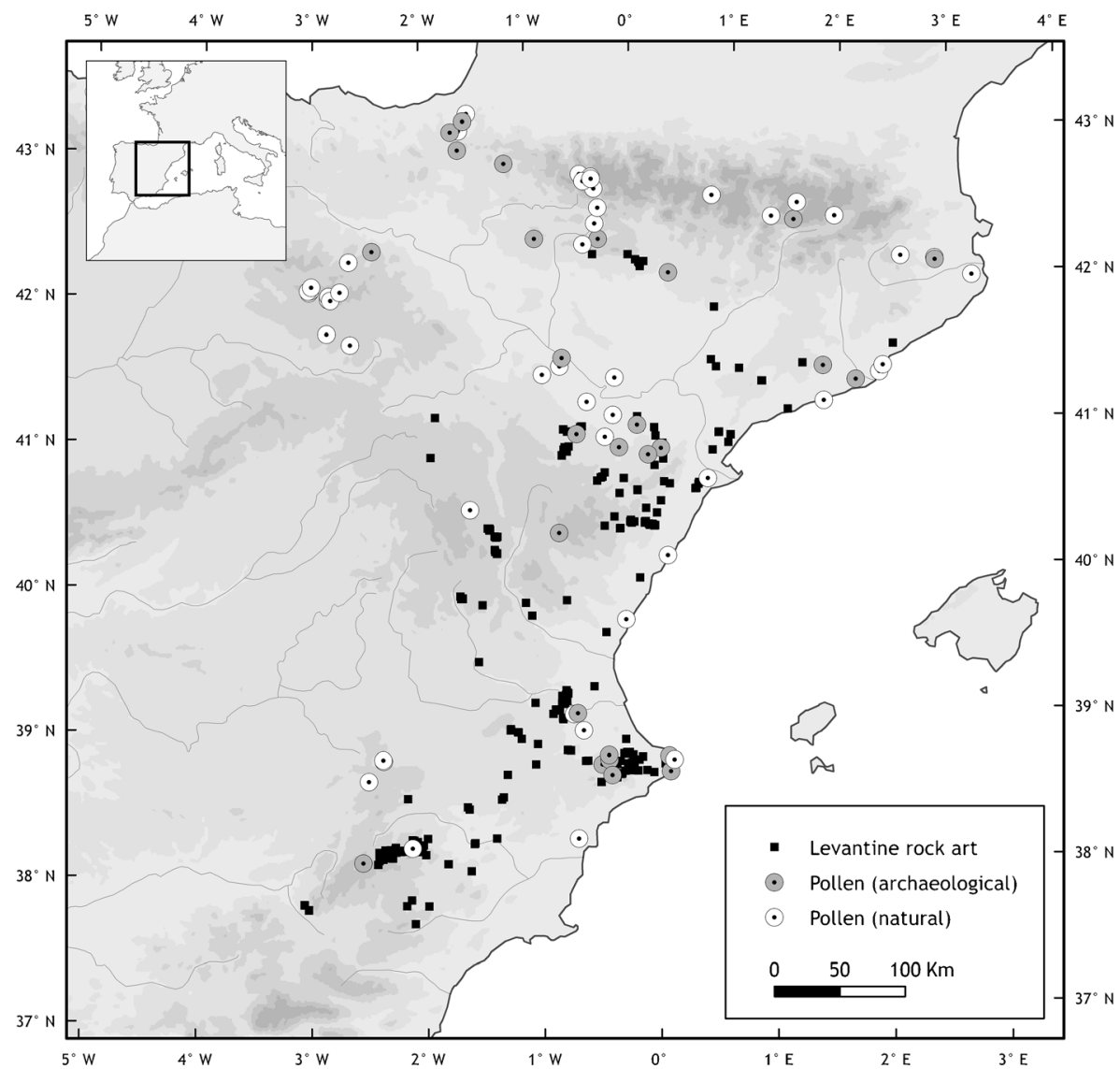

Fig. 1 Pollen samples from natural and archaeological deposits, and Levantine rock art sites

areas for pasture (López-García and López-Sáez 2000; López-Sáez et al. 2006). More data from Aragón showing early evidence of modification of the environment through fire come from Botiquería del Moros (Mazaleón, Teruel; López-García et al. 1991; López-García and López-Sáez 2000), and El Pontet (Maella, Zaragoza; López-García 1992; López-García and López-Sáez 2000).

In the Southern Iberian System, some evidence of human intervention through fire around $6,800 \mathrm{cal} \mathrm{BP}^{3}$ could be interpreted from Ojos del Tremedal, possibly linked to grazing due to the parallel emergence of a livestock indicator (Plantago lanceolata; Stevenson 2000).

In south-eastern Spain, the intensity and timing of human impact on vegetation varied among regions. Peripheral and lowland sites such as Navarrés, Elx, and Salines (Burjachs et al. 1997; Carrión and van Geel 1999) show anthropogenic pollen indicators since Neolithic and Chalcolithic times, but there is no firm palynological evidence of human disturbance in the Baetic mountain range (Carrión 2001b, c, 2002; Carrión et al. 2001b, 2004, 2007) until later periods (López-Sáez et al. 2011). Above

\footnotetext{
${ }^{3}$ This date, as well as the dates provided in footnote 4 , are not absolute datations but estimates made by the authors from the curve age-depth elaborated for the respective deposits.
} 
all, the problem seems to be that direct relationships between human occupation maxima and severe ecological disturbance cannot be established (Carrión et al. 2007, p. 1471). However, as in other mountain ranges of the Iberian Peninsula (López Sáez et al. 2009), grazing may have occurred for thousands of years before the last millenium, leaving no traces in the landscape. The Baetic mountain range is indeed a suitable place for grazing and human habitation in the summer, and it is therefore conceivable that high-altitude vegetation was pushed higher by locally increased grazing pressure (Carrión et al. 2001a).

It is possible to see these pieces of data as evidence of human activities taking place in high and mid-elevation areas well before conventional anthropogenic pollen indicators can show them in the record in full-fledged fashion (Carrión 2002). ${ }^{4}$ Human occupation was sparse throughout the area from the Neolithic to the Bronze age. Since there is no firm evidence concerning the intensification of agriculture before Roman times (Buxó 1997), economic activities were probably linked to an extensive economic exploitation, specifically for the creation of pastures. Seasonal movements in search of pastures have been proposed already for the Early Neolithic in the Mediterranean coast of Valencia, and there are both rock shelters and caves that present evidence of use as occasional corrals during that early time (Bernabeu 1995; Bernabeu et al. 2002).

Although the debate about the human role in Mediterranean mountain environments, and its impact, is not closed, in our opinion, the existing evidence tends to support that mountains were not isolated and marginal environments, but important reservoirs of economic resources at least since the beginning of the Neolithic as it is the case in other Western Mediterranean areas (Barker 2005; Robb 2007). The existence of rock art in those chronologies would also support this idea.

\section{The Location of Levantine Paintings}

Rock art in the Spanish Mediterranean basin is a compound of three styles of painting: Levantine, Schematic, and Macroschematic. These paintings are found in a largely fragmented area under very different conditions - a small-scale 'Mediterranean'-, comprising the Pre-Pyreneean mountains to the Baetic Range. Middle-range mountainous settings are clearly priority locations for rock art, but sites are also found at high altitudes and in coastal areas.

We have only considered Levantine rock art in this paper. It has been dated, not without discussion, to the Neolithic. The evidence for this date is mostly indirect, based on iconography (see Cruz Berrocal 2005; Cruz Berrocal and Vicent 2007), and

\footnotetext{
${ }^{4}$ In the Baetic ranges, for instance, Riccia, a non-pollen palynomorph indicative of local grazing, appears earlier at high altitudes (Cañada de la Cruz, ca. 3,700 cal BP), in oromediterranean biotopes, probably because extensive pastures were naturally found here rather than at lower altitudes, in the supramediterranean ones, where the dates are much recent (Siles, ca. 2,400 cal BP) (Carrión et al. 2001a; Carrión 2002). In contrast, Plantago and other indicators of agriculture, arboriculture, and forest degradation, appear first in the pollen record of lowland sites (Villaverde, ca. 2,200-1,660 cal BP) than in the upland ones (Siles, ca. 1,400 cal BP; El Sabinar, ca. 1,353 cal BP; Cañada de la Cruz, ca. 670 cal BP) (Carrión et al. 2001a, b, 2004; Carrión 2002).
} 
the only existing absolute datation established an open chronological framework prior to $6,180 \pm 35 \mathrm{BP}(7,170-6,960 \mathrm{cal} \mathrm{BP})$ at least in the Cuenca region (Ruiz et al. 2006).

The chronological attribution of the paintings is independent of any environmental or locational consideration. Rock art is thus an independent reference in a landscape study, as shown at the regional and local scales in Cruz Berrocal (2004, 2005), Cruz Berrocal and Vicent (2007), Fairén (2006), Ruiz (2006), Martínez and Rubio (2010) and Sebastián López (2011). Results from these analyses are encouragingly consistent: the location of the rock art sites shows clear trends. Following the experimental inferential approach proposed by Vicent (1991) for the geographical study of the location of archaeological sites, we have performed GIS and statistical analysis ${ }^{5}$ based on a set of relevant landscape variables in order to test the existence of these locational patterns.

According to this methodology, we have compared the characteristics of Levantine rock art locations against those of a control random sample that we presume summarize the structural landscape features of the Mediterranean facade of the Iberian Peninsula. Despite the likely geographical variability contained in such a wide area, the analysis has been performed at a macro-regional scale, considering the whole set of Levantine rock art sites as a consistent phenomenon with identifiable common features.

We have used a set of 370 rock art sites drawing on the information contained in the Dossier UNESCO, produced by the Spanish Autonomous Communities for the declaration of this rock art as World Heritage. The information was later completed by our own fieldwork. Each rock art site has been georeferenced by a pair of $X Y$ coordinates. We have generated an equal-size random sample of point locations ${ }^{6}$ within a previously defined study region. This region consists of a 50-km buffer around Levantine rock art sites, excluding the sea (Fig. 2). This fixed distance represents a two-day-walking hinterland, easily consistent with a trasterminantbased economic territory. An alternative procedure for the definition of the study area - the use of real geographical features such as river basins - was considered, but it was discarded because it included areas quite far from Levantine rock art sites. In order to test the randomness of the control sample, we performed a nearest neighbor analysis $^{8}$ with positive results. ${ }^{9}$

The surroundings of each location - rock art sites and random points - have been established by means of a $1-\mathrm{km}$ circular buffer around its coordinates point. Each buffer has been characterized through a series of geographical layers that we consider relevant structural factors of the landscape, useful to contrast general hypotheses about prehistoric economies (Fernández-Freire and Uriarte 2011). These layers, and the digital cartography used to implement them in the GIS, are:

\footnotetext{
${ }^{5}$ ArcGIS (v. 10) has been used for managing, extracting, and tabulating geographical variables and IBM SPSS Statistics (v. 19) and Stata (v. 10) for analyzing them. Coordinate system selected for GIS layers is UTM 30 North, European Datum 1950.

${ }^{6}$ ArcGIS-ArcToolbox-feature class-create random points

${ }^{7}$ ArcGIS-ArcToolbox-analysis tools-proximity-buffer

${ }^{8}$ ArcGIS-ArcToolbox-spatial statistics tools-analyzing patterns-average nearest neighbor

${ }^{9}$ Nearest neighbor ratio $=1.023 ; z$ score $=0.855, p$ value $=0.397$.
} 


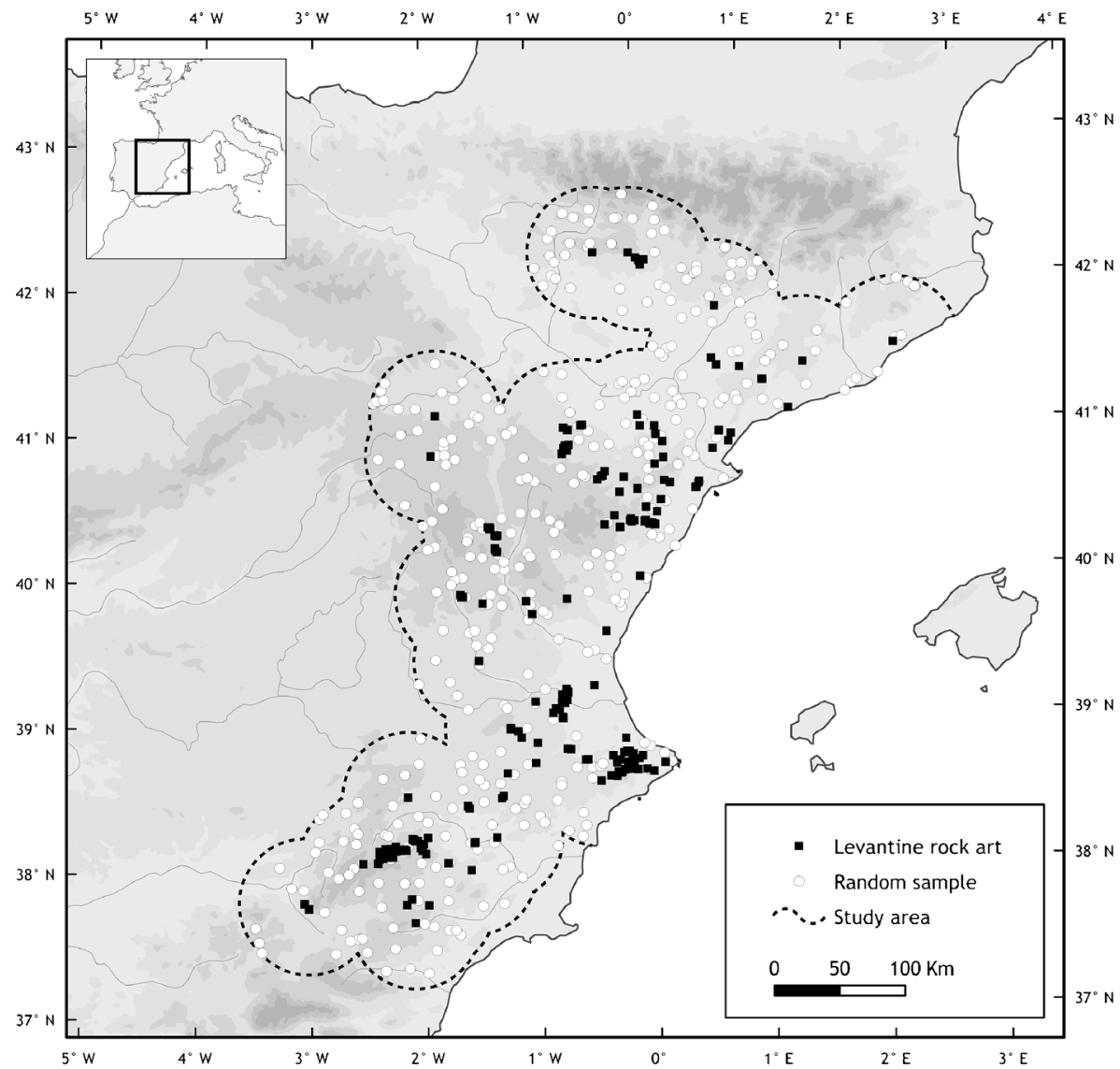

Fig. 2 Levantine rock art sites, 50-km-buffer areas, and random points sample

- Elevation (meters above sea level): It has a structural relevance in landscape configuration, mainly in the morphology of economic territories and their bioclimatic features. The digital elevation model used is the SRTM DEM, produced by the NASA. ${ }^{10}$ We have used the version processed and distributed by the CGIAR Consortium for Spatial Information ${ }^{11}$ (Jarvis et al. 2008).

- Slope (percentage): Slope is a strong conditioning factor in landscape exploitation. Steep terrain limits agriculture severely and makes forest and pasture uses the most viable option in paleotechnic conditions. The slope layer has been generated from the digital elevation model through GIS analysis. ${ }^{12}$

- Annual rainfall (millimeter per square meter): It determines the natural availability of water for vegetation cover development and its potential use for grazing or dryland agriculture. The layer used forms part of the Digital Climatic Atlas of the Iberian Peninsula ${ }^{13}$ (Ninyerola et al. 2005).

\footnotetext{
${ }^{10}$ Shuttle Radar Topography Mission: http://www2.jpl.nasa.gov/srtm/

${ }^{11}$ CGIAR-CSI SRTM 90m Digital Elevation Data: http://srtm.csi.cgiar.org/

12 ArcGIS-ArcToolbox-spatial analyst tools-surface-slope

13 Digital Climatic Atlas of the Iberian Peninsula: http://opengis.uab.es/wms/iberia/en_index.htm
} 
- Average of maximum temperatures in July (degrees Celsius): Summer temperatures influence draught and consequently pasture availability in this season. This layer has also been taken from the Digital Climatic Atlas of the Iberian Peninsula.

- Bioclimatic levels: Defined by Rivas Martínez (1987) for the Spanish context, these are general altitude or latitude zones with characteristic climatic and biogeographical traits. They have been taken from the digital version of the Vegetation Series Map of Spain. ${ }^{14}$ We have considered the four following levels as representative of our study area: termomediterranean, mesomediterranean, supramediterranean, and montane. The first three levels, much more widespread, belong to the Mediterranean biogeographical region and include various kinds of vegetation series from more to less sclerophyllous. The montane level, only present in the Pyrenees in our study region, belongs to the Eurosiberian biogeographical region and is related to vegetation series adapted to moister conditions.

- Soil types: the layer used is the soil map of Spain 1:1,000,000 ${ }^{15}$ (Gómez-Miguel 2006), based on the USDA Soil Taxonomy (Soil Survey Group 2003). Four widespread soils have been selected, all typical of Mediterranean environments: inceptisol xerept (soil with a certain edaphic development and a certain presence of organic matter), entisol orthent (thin soil without edaphic development, with main presence of its lithologic substratum), entisol fluvent (non-developed soil, formed on alluvial land), and aridisol calcid (soil typical of Mediterranean arid areas, poor in organic matter and rich in calcium carbonate).

- Land uses: We have considered three basic land uses representative of Mediterranean landscape exploitation (Gilman and Thornes 1985, pp. 38-40): forest and pastoral activities, dryland agriculture, and irrigation agriculture. We have elaborated a GIS layer of these three classes using as data source the Corine Land Cover (version 2000). ${ }^{16}$ We assume that present-day land uses reflect basic structural land use potentialities in a general scale, despite the huge temporal gap and the obvious techno-economical changes. The Corine Land Cover categories have been reclassified into a few general groups: sea, inland water, urban, improductive, forest and pastoral activities, dryland agriculture, and irrigation agriculture. We have just worked the last three, considering the rest as "indeterminate".

From these layers, we have computed a series of variables for describing the buffer areas (Table 1). For those layers representing a continuous quantitative magnitude (elevation, slope, annual rainfall, and average of maximum temperatures in July) we have calculated two values: mean, as a summary of the central tendency, and standard deviation, as a measure of variability. ${ }^{17}$ For qualitative layers (bioclimatic levels, soil types, and land uses), we have considered each majority value (see above) and calculated its area percentage into each $1-\mathrm{km}$ buffer. ${ }^{18}$ The result is a

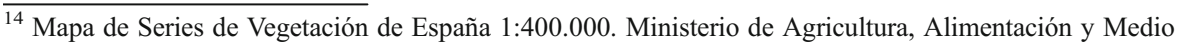
Ambiente: http://www.magrama.gob.es/

${ }^{15}$ Mapa de Suelos de España 1:1,000,000. Instituto Geográfico Nacional. Centro Nacional de Información Geográfica.

${ }^{16}$ Corine Land Cover 2000 (CLC2000). European Environmental Agency: http://www.eea.europa.eu/dataand-maps/data/corine-land-cover-2000-clc2000-seamless-vector-database

${ }_{17}$ ArcGIS-ArcToolbox-spatial analyst tools-zonal-zonal statistics as table

18 ArcGIS-ArcToolbox-analysis tools-overlay-intersect
} 
landscape factor model (Díaz 1984 quoted in Vicent 1991, pp. 40-47) represented in a table with 740 records (370 rock art sites and 370 random points) and the computed variables that characterize their surroundings.

In order to compare the rock art sites group against the random sample, this table has been statistically analyzed variable by variable, both descriptively and inferentially through significance tests (these have been performed at a $95 \%$ significance level, with $p$ values below 0.05 ):

- On one hand, we have inferentially compared the central tendency through significance tests: the Student's $t$ test for those variables that are means and standard deviations, and the Mann-Whitney test for percentages.

- On the other hand, we have compared the distributions. First, we have descriptively examined differences in value frequencies through graphs, both density functions and bar charts. Second, we have used the Kolmogorov-Smirnov test to check if such differences are statistically significant or not.

The results of the statistical analysis (Figs. 3, 4, 5, 6, and 7; Tables 2, 3, 4, 5, and 6) have been interpreted in the following way:

Table 1 Summary of variables used in the analysis

\begin{tabular}{|c|c|c|c|c|}
\hline \multirow[t]{2}{*}{ Geographical layer } & \multirow[t]{2}{*}{ Variable (1-km buffer) } & & \multicolumn{2}{|l|}{ Mean value } \\
\hline & & & Levantine rock art & Random sample \\
\hline \multirow[t]{2}{*}{ Elevation (m) } & \multirow[t]{2}{*}{ Elevation (m) } & Mean & 794.88 & 740.43 \\
\hline & & Std. dev. & 59.77 & 41.40 \\
\hline \multirow[t]{2}{*}{ Slope (pct.) } & \multirow[t]{2}{*}{ Slope (m) } & Mean & 20.74 & 13.78 \\
\hline & & Std. dev. & 12.19 & 7.61 \\
\hline \multirow[t]{2}{*}{ Annual rainfall (mm) } & \multirow[t]{2}{*}{ Annual rainfall (mm) } & Mean & 558.43 & 525.70 \\
\hline & & Std. dev. & 69.40 & 36.81 \\
\hline \multirow[t]{2}{*}{ Ave. max. temp. July $\left({ }^{\circ} \mathrm{C}\right)$} & \multirow[t]{2}{*}{ Av. max. temp. July $\left({ }^{\circ} \mathrm{C}\right)$} & Mean & 30.39 & 30.70 \\
\hline & & Std. dev. & 0.17 & 0.13 \\
\hline \multirow[t]{4}{*}{ Bioclimatic levels } & Termomediterranean & Area pct. & 7.12 & 8.20 \\
\hline & Mesomediterranean & Area pct. & 59.08 & 51.89 \\
\hline & Supramediterranean & Area pct. & 32.65 & 29.61 \\
\hline & Montane & Area pct. & 1.14 & 6.22 \\
\hline \multirow[t]{4}{*}{ Soil types } & Aridisol calcid & Area pct. & 4.26 & 15.47 \\
\hline & Entisol fluvent & Area pct. & 1.93 & 8.07 \\
\hline & Entisol orthent & Area pct. & 40.76 & 35.48 \\
\hline & Inceptisol xerept & Area pct. & 51.05 & 30.35 \\
\hline \multirow[t]{3}{*}{ Land uses } & Forest and pastoral activities & Area pct. & 76.65 & 49.15 \\
\hline & Dryland agriculture & Area pct. & 18.39 & 34.47 \\
\hline & Irrigation agriculture & Area pct. & 3.12 & 11.66 \\
\hline
\end{tabular}



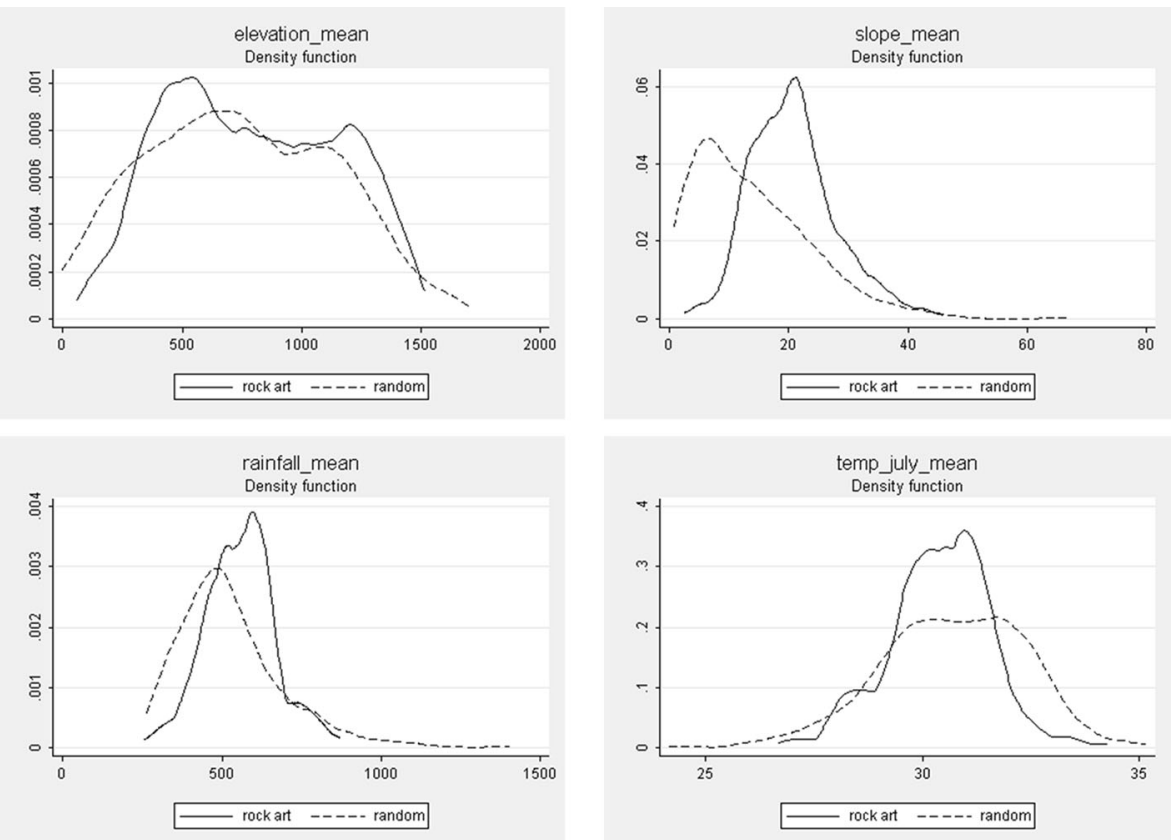

Fig. 3 Quantitative variables (means). Comparison of density functions of Levantine rock art and random sample
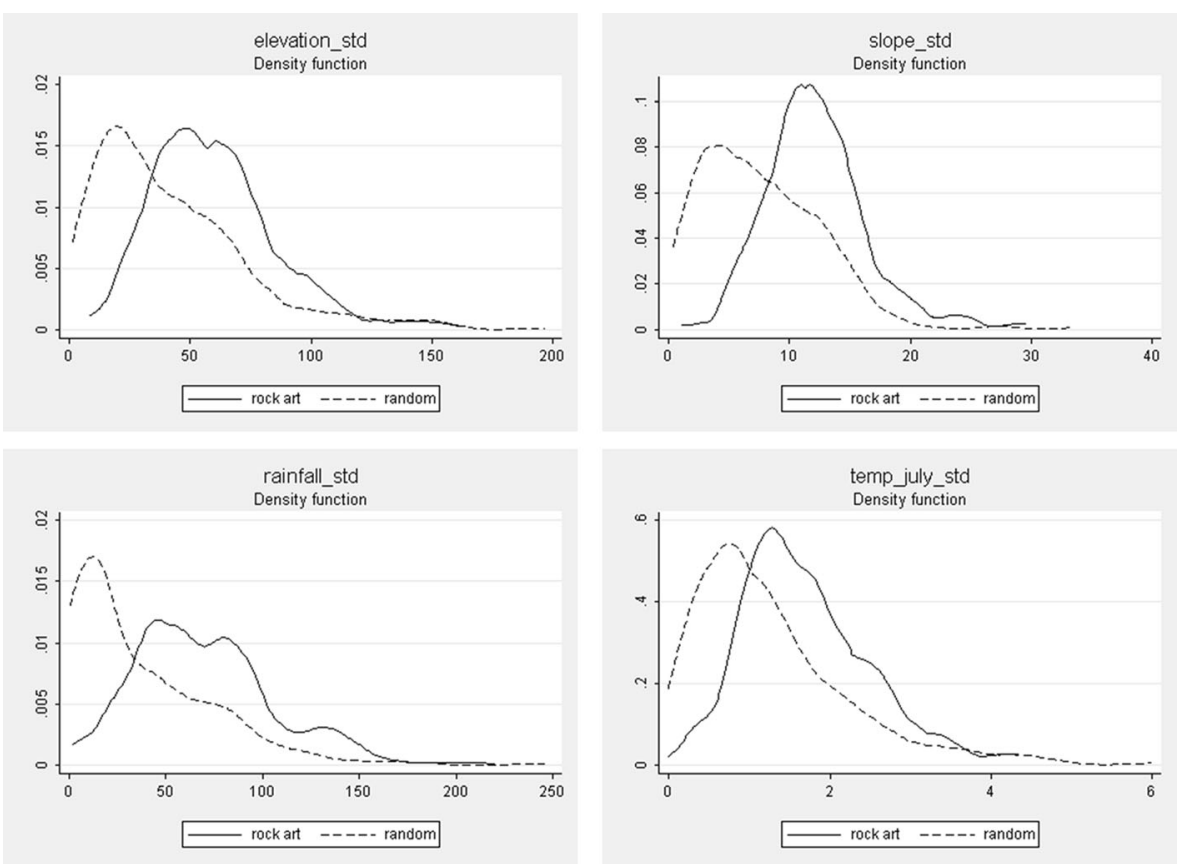

Fig. 4 Quantitative variables (standard deviations). Comparison of density functions of Levantine rock art and random sample 


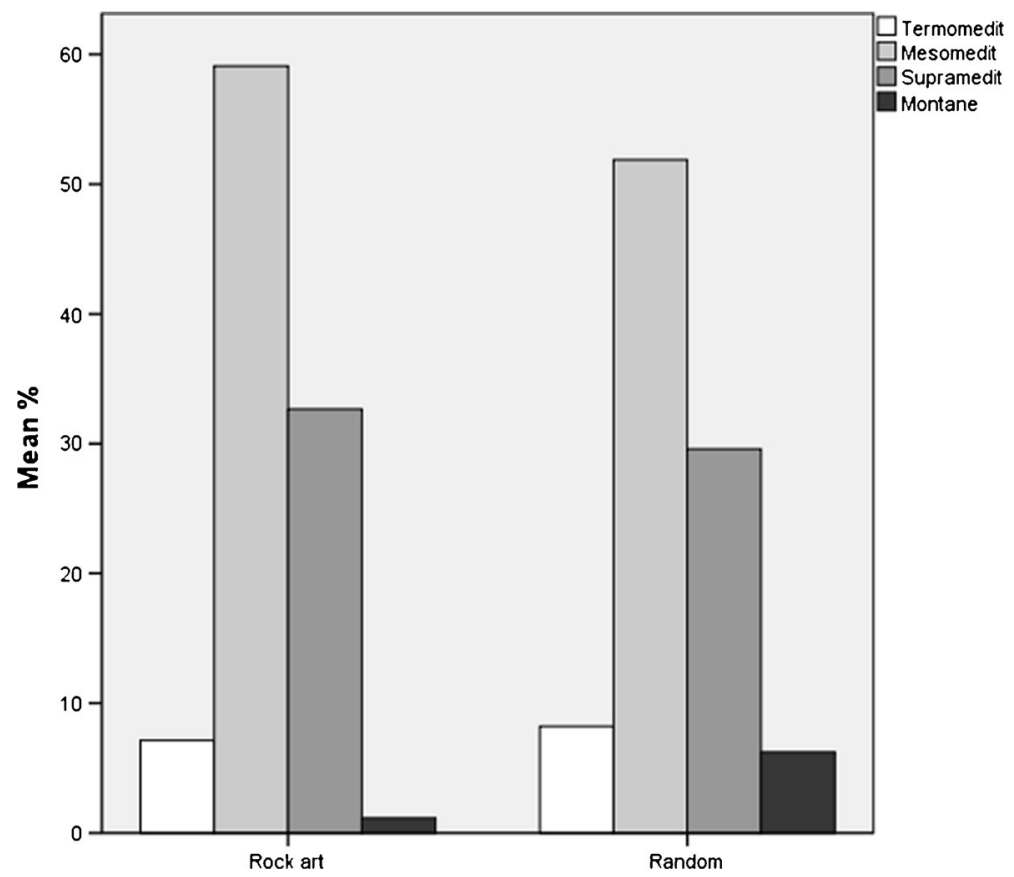

Fig. 5 Bioclimatic levels (area percentages). Comparison of bar charts of Levantine rock art and random sample

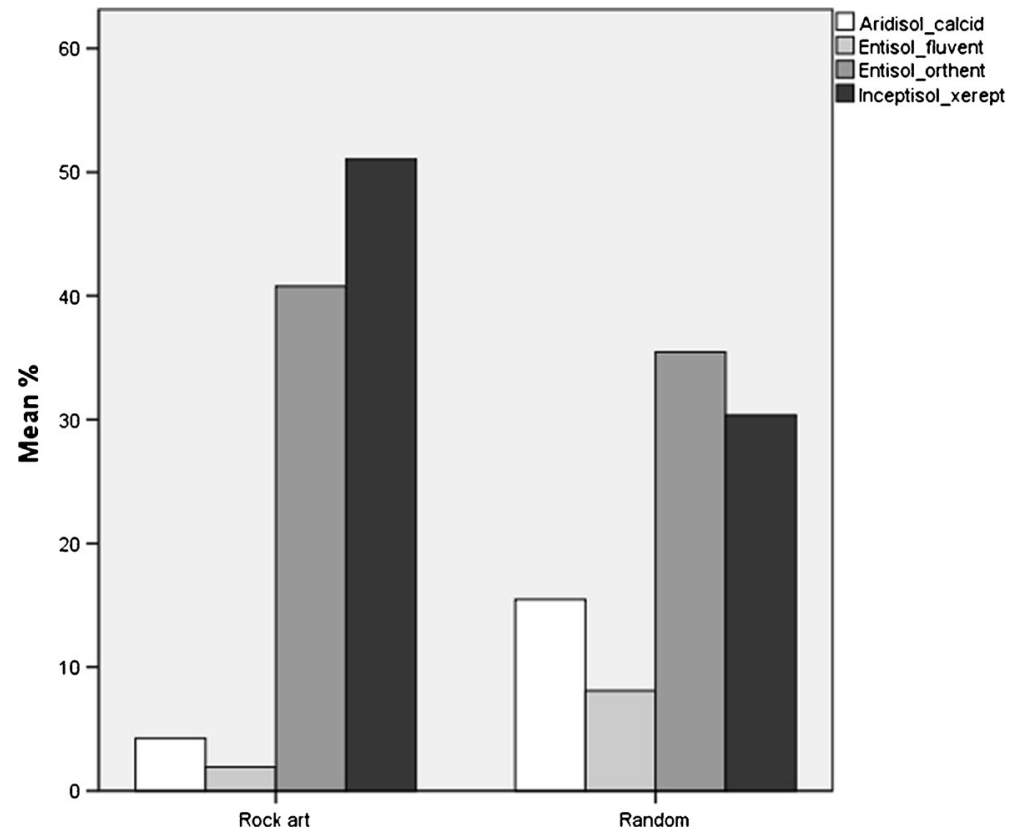

Fig. 6 Soil types (area percentages). Comparison of bar charts of Levantine rock art and random sample 


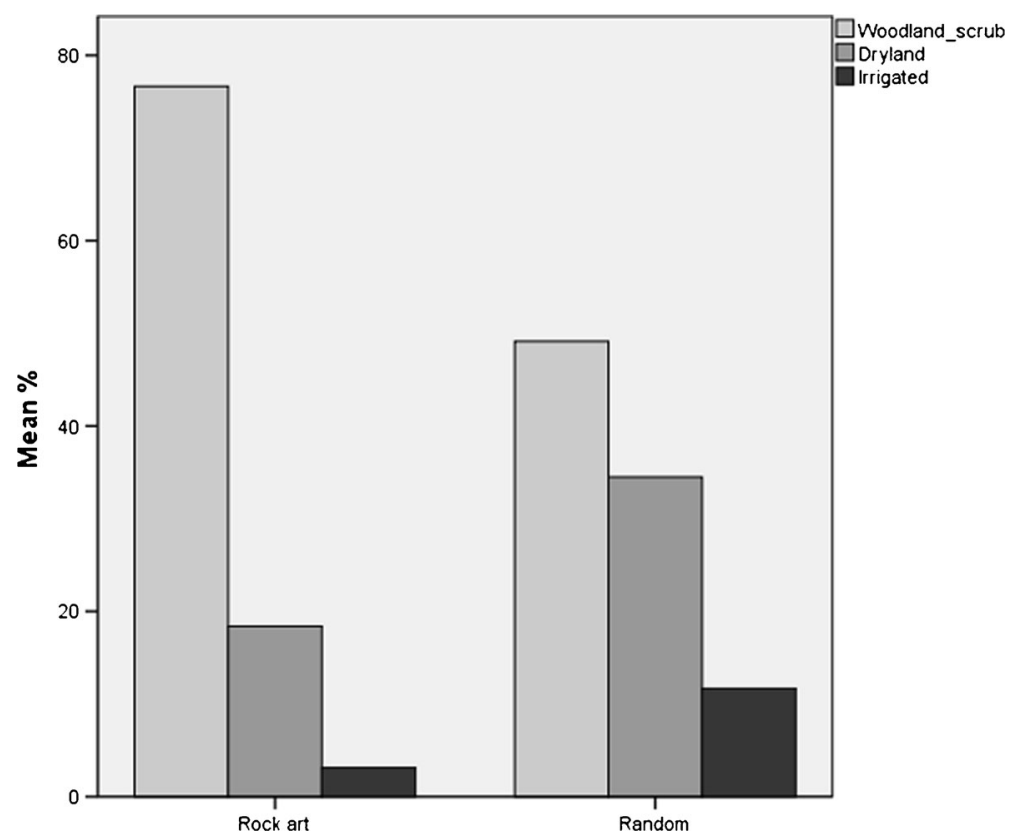

Fig. 7 Land uses (area percentages). Comparison of bar charts of Levantine rock art and random sample

- In overall terms, most of variables show a significant difference between rock art sites and the random sample, so we can assume that the first have a quite strong non-random location pattern, preferring some landscape features to others.

- Regarding the four continuous variables (elevation, slope, rainfall, summer temperature; Table 2), their means all give significant differences in their central tendency ( $t$ test). Rock art sites occupy higher, steeper, rainier, and less hot environments, traits consistent with an economic strategy directed to mountain resources, although we must recognize that differences between means are too subtle in geographical terms, except in the case of slope. Nevertheless, comparison between distributions (Fig. 3) and Kolmogorov-Smirnov test results (Table 2) reinforce and complement the "mountain" interpretation. Rock art sites tend to avoid extreme values and occupy a more or less wide intermediate fringe, loosely related to mid-altitude environments.

Table $2 t$ test and KolmogorovSmirnov test of quantitative variables (means)

Groups: 1 Levantine rock art; 2

\begin{tabular}{lcrcc}
\hline Variable & Group & Mean & Sig. $(t)$ & Sig. (KS) \\
\hline Elevation (mean) & 1 & 794.88 & 0.046 & 0.007 \\
& 2 & 740.43 & & \\
Slope (mean) & 1 & 20.74 & 0.000 & 0.000 \\
& 2 & 13.78 & & \\
Rainfall (mean) & 1 & 558.43 & 0.002 & 0.000 \\
& 2 & 525.70 & & \\
July temp. (mean) & 1 & 30.39 & 0.004 & 0.000 \\
& 2 & 30.70 & & \\
\hline
\end{tabular}
random sample 
Table $3 t$ test and KolmogorovSmirnov test of quantitative variables (standard deviations)

Groups: 1 Levantine rock art; 2 random sample

\begin{tabular}{lcrcc}
\hline Variable & Group & Mean & Sig. $(t)$ & Sig. (KS) \\
\hline Elevation (std. dev.) & 1 & 59.77 & 0.000 & 0.000 \\
& 2 & 41.40 & & \\
Slope (std. dev.) & 1 & 12.19 & 0.000 & 0.000 \\
& 2 & 7.61 & & \\
Rainfall (std. dev.) & 1 & 69.40 & 0.000 & 0.000 \\
& 2 & 36.81 & & \\
July temp. (std. dev.) & 1 & 0.17 & 0.000 & 0.000 \\
& 2 & 0.13 & & \\
\hline
\end{tabular}

- The results of the standard deviations of the same continuous variables are even more conclusive. Both graphs and test results (Fig. 4, Table 3) clearly show that rock art sites surroundings tend to be more diverse. This striking pattern can be interpreted as a search for environmental diversity, perhaps in transitional zones between biotopes where it is easier to combine different exploitation strategies.

- Regarding bioclimatic levels, differences are not clear neither conclusive (Fig. 5, Table 4). Perhaps the main contrast is in the montane level, almost absent in the rock art group, stressing a certain preference for typical Mediterranean environments from the biogeographical point of view.

- Results about soils show a certain preference for inceptisols xerept and an underrepresentation of aridisols calcid and entisols fluvent (Fig. 6, Table 5). Levantine rock art sites seem to prefer relatively developed soils over arid lands and alluvial zones, searching those places that favor the development of vegetation cover (excluding riparian).

- Finally, land uses offer a clear predominance of wild vegetation (such as forest, scrub, or grassland) over agricultural areas, both dryland and irrigation (Fig. 7, Table 6).

In sum, the location chosen for Levantine rock art sites tend to prioritize a series of environmental features over the standard characteristics of the study area:

- "Wild" landscape with a clear predominance of rough terrain and extensive lands uses.

- Viability and stability of vegetation formations, thanks to relatively developed soils and softer climatic conditions.

Table 4 Mann-Whitney and Kolmogorov-Smirnov tests of bioclimatical level percentages

Groups: 1 Levantine rock art; 2 random sample

\begin{tabular}{lcccc}
\hline Variable (levels) & Group & Mean rank & Sig. (MW) & Sig. (KS) \\
\hline Termo & 1 & 375.03 & 0.288 & 0.976 \\
\multirow{2}{*}{ Meso } & 2 & 365.97 & & \\
& 1 & 386.79 & 0.034 & 0.000 \\
Supra & 2 & 354.21 & & \\
& 1 & 374.60 & 0.550 & 0.021 \\
Montane & 2 & 366.40 & & \\
& 1 & 360.86 & 0.001 & 0.652 \\
& 2 & 380.14 & & \\
\hline
\end{tabular}


Table 5 Mann-Whitney and Kolmogorov-Smirnov tests of soil type percentages

Groups: 1 Levantine rock art; 2 random sample

\begin{tabular}{lcccc}
\hline Variable (soils) & Group & Mean rank & Sig. (MW) & Sig. (KS) \\
\hline Inceptisol xerept & 1 & 414.98 & 0.000 & 0.000 \\
& 2 & 326.02 & & \\
Entisol orthent & 1 & 381.55 & 0.135 & 0.008 \\
& 2 & 359.45 & & \\
Entisol fluvent & 1 & 354.09 & 0.000 & 0.088 \\
& 2 & 386.91 & & \\
Aridisol calcid & 1 & 344.25 & 0.000 & 0.001 \\
& 2 & 396.75 & & \\
\hline
\end{tabular}

- Diversity in potential resources for economic activities, in environmentally heterogeneous zones.

\section{Interpreting the Patterns}

The regularities shown in the location of the Levantine rock art sites point to a strong adaptation to specific geographical conditions, in order to meet certain requirements which in our view are related to the role of rock art in the social and economic landscape of the Neolithic groups. In particular, we can start to see this role when looking at traces of the strong relationship existing between the rock art shelters and the traditional pastoral way of life and land use.

Fieldwork developed between 1999-2000 and 2008-2009 in Villar del Humo (Cuenca), Albarracín and Tormón (Teruel), Júcar (Valencia), La Sarga (Alicante), Maestrazgo (Castellón), Maestrazgo (Zaragoza), Vero river (Huesca), and Martín River (Teruel) rendered evidence of occupation by shepherds in 3/4 of the rock art sites, be it through hints such as fire marks on the shelter walls, or in the form of pens, built using the shelter as a side wall.

Other sites have been reported to have had such use: among many others, the Abric de Pinós (Hernández et al. 1998, p. 126), Cueva del Garroso and most of the sites in this area (Beltrán and Royo 2001), Barranco del Mortero (río Martín), Abrigo del Secans (Utrilla 2005), Plano del Pulido (Utrilla et al. 2010), Abrigo del Ángel (Utrilla and Bea 2011), Cova de Santa Maira (Badal 1999), Cova del Mansano (Aparicio et al. 1988, p. 19), Cova de la Tia Isabel (Aparicio et al. 1988, p. 41), Cuevas del

Table 6 Mann-Whitney and Kolmogorov-Smirnov tests of land use percentages

Groups: 1 Levantine rock art; 2 random sample

\begin{tabular}{lcccc}
\hline Variable (land uses) & Group & Mean rank & Sig. (MW) & Sig. (KS) \\
\hline Woodland and scrub & 1 & 443.48 & 0.000 & 0.000 \\
& 2 & 297.52 & & \\
Dryland agriculture & 1 & 334.51 & 0.000 & 0.000 \\
& 2 & 406.49 & & \\
Irrigation agriculture & 1 & 341.61 & 0.000 & 0.000 \\
& 2 & 399.39 & & \\
\hline
\end{tabular}


Engarbo (Soria and López 1999, p. 32), Abric de la Falaguera (Bernabeu et al. 2002, p. 173), Coves de la Vila (Hernández et al. 1998, p. 50), Abric de les Torrudanes (Hernández et al. 1998, p. 94), and the following sites described in Ruiz (2006): Rinconada de González (p. 134), Cueva del Tío Modesto (p. 139), Cabeza Sancha (p. 179), Corbeteros I (p. 186), Corbeteros II (p. 195), Corbeteros III (p. 205), Collado del Toro IV (p. 303), Cueva del Bullón (p. 347), Rambla del Anear (p. 382), Collado de la Losa (p. 389), Hoya del Niño I (p. 398), Los Arenales (p. 487), Peñalta (p. 503). They are mostly refuges for shepherds, or they contain structures to pen up livestock.

This kind of information has been consistently neglected in the publications, and the same is true for place names, an interesting and complicated piece of evidence. On the one hand, researchers follow unexplicit and changing criteria to name sites, and many times this has led to a loss of information when the traditional names are not recorded. A second issue is the misunderstanding of the vernacular place name due to linguistic difficulties. But all in all, there is a correlation between rock art sites and names related to husbandry, such as Abrigo de la Paridera de las Tajadas, Abrigo de las Cañadas, Balma de les Ovelles, Cañada de la Cruz, Cerrada del Tío Jorge, Corral de la Gascona, or Mallata, among many others.

Rock shelters are easily converted into pens, receive natural light, and render protection against the elements (Colón Díaz 1998, p. 205). And their situation inside gullies enhances their quality as refuges: $90.9 \%$ of the total sample of sites are sheltered inside gullies, particularly suitable, in terms of size, water, and vegetation, to keep and feed livestock, as the traditional pastoralist activities show. ${ }^{19}$

This is due to the fact that, in the arid and semiarid Mediterranean environments, gullies are a most interesting resource since they hold microclimatic conditions that allow them to retain some humidity, or even water lenses, throughout the year. This means that also vegetation is more likely to endure the summer inside these natural refuges, making them, therefore, particularly suitable as a feeding source for animals. Both water - an essential resource in the karstic areas and the most valued in social terms, and most so in the Mediterranean (Farnós et al. 1993; Colón Díaz 1998; Horden and Purcell 2000) — and vegetation, are strategic resources (Carrión et al. 2000). These microclimatic advantages are also supported by topographical ones, since small-sized gullies favor the management of animals within them (Beltrán 1993; Davidson 1989).

At the broader regional scale, the rock art is located, as shown above, in areas of general limited agricultural potential, but featuring an ecologically transitional character between low- and uplands, or biotopes, that provides a combination of different microenvironments (Rivas Martínez 1982). This favors a set of complementary economic activities, based on pastures and forest. Thus, hunting, gathering, and even some agriculture are possible at the small scale (Bacaicoa et al. 1993; Roigé Ventura et al. 1993; Pallaruelo 1993; Rubio de Lucas et al. 1993a) in combination with

\footnotetext{
${ }^{19}$ Most interestingly, rock art sites tend to be located at particular places inside the ravines, be these the heads, confluences, or mouths. Only in Aragón, Los Estrechos, Los Chaparros (Martín river), Arenal de Fonseca (Ladruñán), and Chimiachas (Vero river) seem to mark the access to gullies; Gallineros and Huerto Raso (Lecina), as well as Benedí (Jaraba), among others, mark the confluence of two ravines. On the other hand, the Cerrao paintings (Obón), Fenellosa (Beceite), Cantalar I, El Mortero (Alacón), Cerro Felío, la Cañada de Marco, Barranco de Solencio, and Prado del Tormón, among many others, mark water sources and naturally occurring water accumulations.
} 
husbandry: grass tends to grow under the forest cover, which allows grazing during summer time (Bacaicoa et al. 1993; Roigé Ventura et al. 1993). Seasonality is in fact one of two very significant aspects of land use in the area; the other is an extensive, low-impact work investment: since forested and open areas compete, pastures have to be maintained through fire (Pallaruelo 1993; Butzer 1996). But this work investment is relatively small, and keeping the forest in check is not a limitation for the exploitation of other resources.

Herding and cultivation in the lowlands are, thus, traditionally, complementary to each other (Butzer 2005), and a sustainable economic activity (Mangas 1992; Butzer 1996; Creighton and Seguí 1998; Sánchez Moreno 1998; Christie et al. 2007), with different dimensions, ranging from mixed husbandry-farming activities to trasterminant short movements between close areas, the likely precedent of trashumance ${ }^{20}$ (Pallaruelo 1993; López Sáez et al. 2009). In all cases, regardless of the local specificities, the seasonal and varied character of these middle-altitude ranges made them very important in traditional rural economies, and especially important as summer pastures in traditional husbandry, well studied by Klein (1990), Bacaicoa et al. (1993), Farnós et al. (1993), Roigé Ventura et al. (1993), Rubio et al. (1993a, b), Pallaruelo (1993), or Fernández Temprado et al. (1996).

The time-depth of the practice is however not well established. Researchers tend to assume that it goes fairly back in time (Butzer 1988; Pallaruelo 1993; Ruiz Gálvez 2002). Seasonal patterns of mobility between Mediterranean up- and lowlands have been traced back to the Palaeolithic and Mesolithic (Aura and Pérez 1992; Aura et al. 1998) and trasterminant movements in search of pastures have been described for the early Neolithic for some areas (Bernabeu 1995), with rock shelters and caves being used as occasional corrals (Bernabeu 1995; Bernabeu et al. 2002), and as research and evidence grow, more regional case studies are highlighted that illustrate continuous husbandry since the Neolithic (e.g., Ejarque and Orengo 2009, or the alternative occupation and abandonment of Cueva de Olvena, close to Remosillo rock art site and dated between the Early Neolithic and Late Bronze Age, interpreted as a stop in the transhumant movement towards Sierra Ferrera). By Roman times, the patterns of husbandry found later on were already in place (Butzer 1988; López Sáez et al. 2009).

Medieval trashumance, on the other hand, has been thoroughly studied (e.g., Butzer 1988; Mangas 1992; Bacaicoa et al. 1993; Farnós et al. 1993; Pallaruelo 1993; Roigé Ventura et al. 1993; Rubio de Lucas et al. 1993a, b; Fernández Temprado et al. 1996; López Sáez et al. 2009), as one example of this type of pastoral institutions in the Mediterranean (Mientjes 2004; Barker 2005). The study of transhumance is only partially useful when tracing back the practice and continuity of the Mediterranean pastoral activities, because certain historical, political, and social factors enabled transhumance - among others, royal privileges allowed the

\footnotetext{
${ }^{20}$ Studies are slightly biased towards research on transhumance, since small-scale movements, directed towards subsistence rather than large-scale economic activities, lacked the social significance and the historic connotations of trashumance, and were therefore hardly considered and recorded, even in later times. There are exceptions, in areas with a very strong altitudinal gradient where some ethnographic work of trasterminant vertical short movements has been done, such as in the Pyrenees (Roigé Ventura et al. 1993), the Baetic Ranges (Alcaraz, Cazorla, and Segura) (Rubio de Lucas et al. 1993a), the Maestrazgo (Fernández Temprado et al. 1996), and the Aitana and Mariola sierras (Fernández Temprado et al. 1996).
} 
institution of the Mesta to gather its power (Davidson 1980; Butzer 1988) — this study is however significant.

Spanish transhumance consisted of massive movements of herds, composed mostly by sheep, from their areas of winter-staying to areas of summer pastures using livestock paths. These movements involved extremely long distances throughout most areas of the Peninsula. The Medieval written documentation reflects what were already traditional rights at the time. Islamic conquerors of the peninsula could have been the introducers of the practice of long-distance movement of sheep, but after Butzer (1988, p. 40), “...overall the Islamic data suggest more continuity than change. In effect, these early Medieval sources provide a longer perspective on the evolution of livestock raising on the peninsula that emphasizes persistence since late prehistoric times, a characteristic that must be attributed to ecological factors". Christian documents about transhumant practices date to the Reconquista (e.g., Klein 1990; Bacaicoa et al. 1993; Roigé Ventura et al. 1993); they show the institutionalization of the practice in the thirteenth century across Sierra Morena, the Prebaetic Ranges (Rubio de Lucas et al. 1993a), between the coastal ranges and the uplands of the Iberian Range (Fernández Temprado et al. 1996), and between Cuenca, Albacete and Murcia (Fernández Temprado et al. 1996, p. 30). In Catalonia, the transhumant system was recorded by documents as early as the eleventh to twelfth centuries, when rural communities took their flocks to the low flat lands for the winter (Roigé Ventura et al. 1993). The first pastoral infrastructures recorded between the Ebro delta and the Turia basin date from the twelfth century (Farnós et al. 1993).

Livestock paths articulate this regional system. They are major lines of contact between up- and lowlands: they clearly establish the link between different and sometimes distant regions, through a dense network of mostly minor pathways.

Livestock paths are, in a sense, archaeological remains. But they are also historically dynamic entities and have changed along time. Butzer (1988, p. 42) described the Spanish network of livestock paths as ".... a complex hierarchy of web-like sheep trails that defies mapping on a national scale. The only fixed points in this unstable pattern appear to have been the royal toll stations (...)". In a previous work (Fairén et al. 2006), we developed some experimental analysis in order to test this statement.

First we tested the hypothesis that the livestock paths correspond to least-cost routes, in an area comprising the Vall d'Albaida (south Valencia) and the middle Serpis basin (north Alicante). The results were negative: the livestock paths tend to follow water divides and sheer zones because they must avoid agricultural fields while at the same time looking for the good pastures that grow in the river basins. Therefore, they go along divides or middle slopes. The livestock paths did correlate with the location of villages in the lowlands, though. The reason is that this region it is a point of departure for herds that go into the uplands. Thus, livestock paths in these areas gather herds from the villages, and villages are, therefore, the most determining factor in their location.

But in the uplands, point of arrival for the herds, the situation is reversed. The paths' courses are much more influenced by other elements, such as the location of water. In these areas, paths are greatly ramified, and their size diminish. The greater the ramification, the greater the stability of the network, thus allowing its preservation. The more inconspicuous the role of livestock paths in the landscape, the more stable and relevant they become in archaeological terms. Overall, livestock paths 
have been preserved fairly well in the uplands, and they are key elements in the regional network of economic activity.

In previous works (Cruz Berrocal 2004, 2005; Fairén et al. 2006; Cruz Berrocal and Vicent 2007), we have shown a geographical correlation between the location of Levantine rock art sites and livestock paths - no rock art site is in isolation or removed from the network created by livestock paths - as well as an overlapping of rock art sites and traditional pastures. This is in our view a major argument to understand the existence and distribution of rock art sites: they can be seen as fixed points within the network, as Butzer (1988, p. 42) thought of the much later royal toll stations. Moreover, they, as the paths, themselves, can be assumed to relate to a set of resources.

\section{The Archaeology of Rock Art As an Archaeology of Landscape}

In a sense, livestock paths make visible the underlying structure of the territory, reproduced by the location of rock art sites, which also 'map' the territory pointing to specific resources (pasture, water, refuge). Thus, rock art sites are archaeologically traceable material expressions of an early integration of the mountainous areas of the Mediterranean basin in people's economic life.

The study of rock art from the point of view of its distribution is therefore a way of undertaking a literal 'archaeology' of the landscape. Its distribution "materialize[s] (...) one single territory out of all the different regions" (Cruz Berrocal and Vicent 2007, p. 689). Unlike settlements - their locational differences through time may be explained in functional, social, cultural or even environmental terms-, rock art allows us to observe a complete landscape (Cruz Berrocal and Vicent 2007), in which lowlands and uplands are linked forming a single regional territory, composed of a series of articulated local areas (Cruz Berrocal 2004, 2005; Cruz Berrocal and Vicent 2007). Thus, rock art shows the interplay of the macro-micro, the connectivity that characterizes the fragmented Mediterranean. ${ }^{21}$ Of course, one major advantage in this regard is that, unlike paths, rock art may be a dated evidence; we can at least assign a terminus post quem to this process of landscape construction.

The correlation between the distribution of the Neolithic paintings and the pastoral traditional landscape may be further interpreted as a continuum in the use of a series of very valuable economic resources in the Mediterranean uplands for as long as several millennia, marked by archaeological indicators pointing to its beginning and possibly its end. Life along this continuum is not easy to grasp archaeologically otherwise. Archaeology and ethnoarchaeology of pastoralism in the Mediterranean is growing (e.g., Creighton and Seguí 1998; Mientjes 2004; Christie et al. 2007) as well

\footnotetext{
${ }^{21}$ Mediterranean mountains "are actually closely integrated into the patterns of production and communication that abut them" (Horden and Purcell 2000, p. 81). Geography shows this: in the Spanish Mediterranean basin, numerous natural corridors link the coast to the inland and mountainous areas-e.g. the Vinalopó and Segura - the first linking the Mediterranean coast with the inland, through the mountain passes of Almansa and Caudete, the second linking the Mediterranean basin with Andalucía and the Guadalquivir basin; or the North-South corridors, such as Alcoià-Comtat, Salinas, Novelda-Monforte del Cid to Alicante, lower Vinalopó to lower Segura, and corridors that link the Alto Maestrazgo with the coast in Castellón, and the Upper Tagus with the Lower Vinalopó/Lower Segura (Ruiz Gálvez 2002).
} 
as studies focused on change and continuity in a specific region (e.g., Ejarque and Orengo 2009). But because of the very nature of these regions and their use, there is scarce or no evidence of settlement in the Mediterranean mountains until the very late periods. Rock art sites themselves are shallow shelters that can hardly retain any sediment, while their locations in gullies prone to seasonal flooding do not contribute further evidence, since archaeological remains would be swept away every season. Therefore, archaeological evidence is scarce. ${ }^{22}$

As for the paintings themselves, there are some intriguing depictions in some of the shelters pointing to continued visits through time (e.g., the equestrian figure in Abrigo X, Cingle de la Gasulla, Castellón, dated to the Iron Age (Ripoll 1962)), but there is no regular repainting on the rock shelters.

This does not necessarily mean that people were not aware of the Neolithic paintings, however. In our fieldwork, we found some evidence of an impact of the Neolithic rock art in the subsequent reconstruction of landscapes later in time. In three of the areas (Gasulla, Villar del Humo, and Albarracín) other rock art depictions were probably made in Medieval times, exactly surrounding the coherent 'systems' formed by the Neolithic rock art sites. Thus, while they 'respect' them, they probably use them as references. In a sense, the Medieval sites are enlargements of the prehistoric constructions, but they are scarce and, somehow, marginal. They can be considered as exceptions (see also Ruiz 2006), as opposed to the Neolithic rock art. Thus, the contrasts probably point to a very different sociological context for the making of the depictions both in Neolithic and Medieval times. In the first case, rock art was inserted in a wider territorial system, and subject to rules as to how and where, and probably who and when, the art should be made, as shown in the clear regularities and patterns that characterize the Levantine paintings. In the case of Medieval rock art, its features point to a set of individual actions that create unique sites with scarce or no regular features among them. As a product of independent and unique events, this rock art does not appear to belong in a broader social logic, as it was the case of the Neolithic paintings; rather, it is the patrimony of specific, even marginal, sections of the society (probably herders), and its materiality has therefore totally changed. Neolithic rock art worked as a social institution, whereas in Medieval times rock art appears as an idiosincratic personal or group expression (Cruz Berrocal 2005). It is not necessarily irrelevant, but it has lost its previous social significance.

In other words, the archaeology of rock art also shows a wider social context through the existence or absence of patterns, and therefore an accordingly changed social significance and even a different social formation behind its making. In our present case it also points to a 'folk knowledge' of the landscape, and to a continuity in the use of places, even under different social and economic conjunctures. Unfortunately, we do not have extensive information about this sort of social memory and knowledge, since it lies at the confluence of three under researched topics: first, the rock art of historic times; second, the relationship between local people and archaeological remains, especially rock art, in Spanish rural areas; and third, the archaeology of mountain areas.

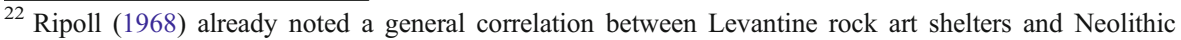
cardial pottery, later reasserted by other findings, and lately, by a number of projects in areas of special concentration of rock art, which show long sequences of settlement throughout the Neolithic and later periods (e.g. Martínez and Villaverde 2002; Hernández and Segura 2002; Ruiz 2006, among others).
} 
Therefore, our proposals are just hints in these directions, approaching now our conclusion: as the evidence of use of the uplands is subtle, almost by definition, especially in early times, it is necessary to weave together different kinds of data and sources, in order to fill the gap, such as maps of potential economic resources and potential erosion, livestock paths, ethnohistorical documentation on herding practices, and palaeoenvironmental records. Rock art may be one of the most important pieces of evidence. The presence of an intentional and highly systematic type of remains such as rock art is enough to demonstrate the social character of this otherwise scarcely imprinted environment. Moreover, basic continuity in the use of the Spanish Mediterranean uplands under a similar exploitative regime can be probably acknowledged since the Neolithic to the contemporary times.

\section{Conclusions}

Levantine rock art sites are a 'map' of the territory; they reflect structural characteristics of the Mediterranean mountain ranges, including topography and seasonal streams, critical within the Mediterranean food production economy. These structural features are not prone to change; they are likely to have remained stable along time. At the same time, human action on the landscape and especifically on the vegetation appears to be detected at around the same time that the making of the rock art, during the Early Neolithic (Carrión et al. 2001b). The patterns of vegetation change reach their maximum complexity between the mid- and late-Holocene. Thus, for instance, although an aridification trend over the last five millennia is well-established, the timing of forest decline is spatially uneven and cannot be solely explained by current differences in physical setting (Carrión 2002). Among the factors involved, the role of anthropogenic disturbance, which was undoubtedly spatially heterogeneous, should be considered. Burning and pastoralism, among other activities, may have been historically decisive and site-specific (Carrión et al. 2007; López Sáez et al. 2009).

Thus the idea of landscape construction, beginning in the Neolithic, is not an abstract proposition: it has material correlates, both 'cultural' and 'environmental'. The human-induced changes in the vegetation have their 'cultural' side in the permanent transformation of the rock shelters, and by the same token, in the permanent transformation of the perception of that landscape. Rock art is then a means of monumentalization, implying a re-conceptualization of space - transformed into a 'place' (Casey 1996) _ and time.

Both environmental and cultural action and construction of the landscape are two early parallel processes in upland Mediterranean areas, dated to the Neolithic. They appear to be intrinsically linked to the long-term history of extensive use of certain resources, almost in between 'domestic hunting' and 'wild husbandry', namely pastoralism, in broad senses. Pastoralism, intended for the creation of surplus (Barker 2005; Robb 2007) and the buffering of risks (Horden and Purcell 2000) in combination with agriculture, is the economic activity that shaped the Mediterranean upland environments (Horden and Purcell 2000; Carrión 2001b; Barker 2005; López-Sáez et al. 2011).

We do not choose to establish a positive and definitive relationship between rock art and pastoralism in the Mediterranean basin, although there are precedents for it (e.g., Martínez 1998, 2000). The environment offers potential good conditions, and 
after Prescott's (1995, p. 168) criteria (domesticates presence, relation to pastures, and potential good natural conditions), it is possible to suggest a reliable link among Neolithic sites, rock art sites, and herding practices - especially of ovicaprids. But we prefer instead to observe rock art as a 'proxy' to understand the underlying structure of the landscape, since the rock art, a permanent feature, kept being 'used' through time. If society and nature form a complex system, the use of environmental markers to reconstruct social history may be supplemented by the use of historical markers to reconstruct, or at least to think, the environment. Rock art studies can benefit from a regional archaeological perspective, but also a regional archaeology can benefit from rock art studies. In fact, we hope to have shown that the study of a territory cannot be effectively completed if the rock art evidence is not taken into account.

Acknowledgments We wish to acknowledge comments and references provided by Agustín Diez Castillo, Juan Gaspar Leal Valladares, Fernando Sedano, and Javier López Precioso. We also thank Juan Ruiz the unpublished manuscript of his doctoral dissertation. Lorenzo Mateos, from ESRI Support, helped in the GIS analysis. José Manuel Rojo, Concepción Murillo, and Ma. Ángeles Toribio, from the CCHSCSIC Statistical Analysis Unit, and Laura Barrios, from the CSIC Scientific Calculus Center, collaborated in the statistical analysis.

This work has partially benefited from financial and technical support provided by the Spanish Consolider Program (CSD2007-00058), and the Spanish Plan Nacional de I+D+i, Ministry of Science and Innovation (projects HAR2008-06477-C03-03/HIST and CGL2011-30512-C02-01).

\section{References}

Aparicio, J., Beltrán, A., \& Boronat, J. (1988). Nuevas pinturas rupestres en la Comunidad Valenciana. Valencia: Academia de Cultura Valenciana, Serie Arqueológica 13 (I).

Aura, J. E., \& Pérez, M. (1992). Tardiglaciar y Postglaciar en la región mediterránea de la Península Ibérica (13500-8500 BP): transformaciones industriales y económicas. Saguntum, 25, 25-47.

Aura, J. E., Villaverde, V., González, M., González, C., Zilhão, J., \& Straus, L. G. (1998). The PleistoceneHolocene transition in the Iberian Peninsula: continuity and change in human adaptations. Quaternary International, 49(50), 87-103.

Bacaicoa, I., Elías, J. M., \& Grande, J. (1993). Albarracín-Cuenca-Molina. Madrid: Cuadernos de la Trashumancia 8, ICONA.

Badal, E. (1999). El potencial pecuario de la vegetación mediterránea: las Cuevas Redil. II Congrés del Neolític a la Península Ibérica. Saguntum-PLAV, 2, 69-75. extra.

Badal, E., \& Roiron, P. (1995). La prehistoria de la vegetación en la Península Ibérica. Saguntum, 28, $29-48$.

Badal, E., Bernabeu, J., \& Vernet, J.-L. (1994). Vegetation changes and human action from the Neolithic to the Bronze Age (7000-4000 B.P.) in Alicante, Spain, based on charcoal analysis. Vegetation History and Archaeobotany, 3, 155-166.

Barker, G. (2005). Agriculture, pastoralism, and Mediterranean landscapes in prehistory. In E. Blake \& A. B. Knapp (Eds.), The archaeology of Mediterranean prehistory (pp. 46-76). Oxford: Blackwell.

Barker, G., \& Bintliff, J. (1999). Geoarchaeology in Mediterranean landscape archaeology: concluding comments. In P. Leveau, F. Trément, K. Walsh, \& G. Barker (Eds.), Environmental reconstruction in Mediterranean landscape archaeology (pp. 207-210). Oxford: The Archaeology of Mediterranean Landscapes 2, Oxbow Books.

Beltrán, A. (1993). Arte prehistórico en Aragón. Zaragoza: Ibercaja.

Beltrán, A., \& Royo, J. (2001). La Cueva del Tío Garroso en el Cerro Felío (Alacón, Teruel). BARA, 4, $23-60$.

Berger, J.-F., Nuninger, L., \& Van Der Leeuw, S. (2007). Modeling the role of resilience in socioenvironmental co-evolution: the Middle Rhône Valley between 1000 BC and AD 1000. In T. Kohler \& S. van der Leeuw (Eds.), The model-based archaeology of socionatural systems (pp. 41-59). Santa Fe: SAR Press.

Bernabeu, J. (1995). Origen y consolidación de las sociedades agrícolas. El País Valenciano entre el Neolítico y la Edad del Bronce. Actes de les Segones Jornades d'Arqueologia (pp. 37-60). Alcofás del Pi: Conselleria de Cultura. Generalitat de València. 
Bernabeu, J., Aura, J. E., \& Badal, E. (1993). Al oeste del Edén. Las primeras sociedades agrícolas en la Europa mediterránea. Historia Universal Prehistoria 4. Madrid: Síntesis.

Bernabeu, J., Orozco, T., \& Díez, A. (2002). El poblamiento neolítico: desarrollo del paisaje agrario en les Valls de l'Alcoi. In M. S. Hernández, J. M. Segura Martí (Coords.), La Sarga. Arte rupestre y territorio (pp. 171-184). Alcoi: Ayuntamiento de Alcoi, Caja de Ahorros del Mediterráneo.

Bintliff, J. (2002). Time, process and catastrophism in the study of Mediterranean alluvial history: a review. World Archaeology, 33(3), 417-435.

Burjachs, F., Giralt, S., Roca, J. R., Seret, G., \& Julià, R. (1997). Palinología holocena y desertización en el Mediterráneo Occidental. In J. J. Ibáñez, B. Valero, \& C. Machado (Eds.), El paisaje mediterráneo a través del espacio y del tiempo. Implicaciones en la desertificación (pp. 379-394). Logroño: Geoforma Ediciones.

Butzer, K. (1988). Cattle and sheep from old to new Spain: historical antecedents. Annals of the Association of American Geographers, 78(1), 29-56.

Butzer, K. (1996). Ecology in the long view: settlement histories, agrosystemic strategies, and ecological performance. Journal of Field Archaeology, 23(2), 141-150.

Butzer, K. (2005). Environmental history in the Mediterranean world: cross-disciplinary investigation of cause-and-effect for degradation and soil erosion. Journal of Archaeological Science, 32, 1773-1800.

Buxó, R. (1997). Arqueología de las Plantas. Barcelona: Crítica.

Carrión, J. S. (2001a). Condicionantes de la respuesta vegetal al cambio climático. Una perspectiva paleobiológica. Acta Botanica Malacitana, 26, 157-176.

Carrión, J. S. (2001b). Dialectic with climatic interpretations of Late-Quaternary vegetation history in Mediterranean Spain. Journal of Mediterranean Ecology, 2, 145-156.

Carrión, J. S. (2001c). Pastoreo y vulnerabilidad de la vegetación en la alta montaña mediterránea durante el Holoceno. Cuadernos de Geografia, 69(70), 7-22.

Carrión, J. S. (2002). Patterns and processes of Late Quaternary environmental change in a montane region of southwestern Europe. Quaternary Science Reviews, 21, 2047-2066.

Carrión, J. S., \& van Geel, B. (1999). Fine-resolution Upper Weichselian and Holocene palynological record from Navarrés (Valencia, Spain) and a discussion about factors of Mediterranean forest succession. Review of Palaeobotany and Palynology, 106, 209-236.

Carrión, J. S., Munuera, M., Navarro, C., \& Sáez, F. (2000). Paleoclimas e historia de la vegetación cuaternaria en España a través del análisis polínico. Viejas falacias y nuevos paradigmas. Complutum, $11,115-142$.

Carrión, J. S., Munuera, M., Dupré, M., \& Andrade, A. (2001a). Abrupt vegetation changes in the Segura Mountains of southern Spain throughout the Holocene. Journal of Ecology, 89, 783-797.

Carrión, J., Andrade, A., Bennet, K., Navarro, C., \& Munuera, M. (2001b). Crossing forest thresholds: inertia and collapse in a Holocene sequence from south central Spain. The Holocene, 11, 635-653.

Carrión, J. S., Yll, E. I., Willis, K. J., \& Sánchez, P. (2004). Holocene forest history of the eastern plateaux in the Segura Mountains (Murcia, southeastern Spain). Review of Palaeobotany and Palynology, 132, 219-236.

Carrión, J. S., Fuentes, N., González-Sampériz, P., Sánchez Quirante, L., Finlayson, C., Fernández, S., \& Andrade, A. (2007). Holocene environmental change in a montane region of southern Europe with a long history of human settlement. Quaternary Science Reviews, 26, 1455-1475.

Carrión, J. S., Fernández, S., González-Sampériz, P., Gil-Romera, G., Badal, E., Carrión-Marco, Y., LópezMerino, L., López Sáez, J. A., Fierro, E., \& Burjachs, F. (2010). Expected trends and surprises in the Lateglacial and Holocene vegetation history of the Iberian Peninsula and Balearic Islands. Review of Palaeobotany and Palynology, 162, 458-475.

Casey, E. (1996). How to get from space to place in a fairly short stretch of time. In S. Feld \& K. H. Basso (Eds.), Senses of Place (pp. 13-52). School of American Research. Advanced Seminar Series (pp. 1352). Santa Fe: School of American Research Press.

Christie, N., Beavitt, P., Gisbert Santonja, J., Gil Senís, V., \& Seguí, J. (2007). Peopling the Recent Past in the Serra de L'Altmirant: Shepherds and Farmers at the Margins. International Journal of Historical Archaeology, 11, 304-321.

Colón Díaz, M. (1998). Montaña y karst mediterráneo. Especificidad, antropización y gestión ambiental. Cádiz: Universidad de Cádiz.

Creighton, O. H., \& Seguí, J. R. (1998). The ethnoarchaeology of abandonment and post-abandonment behaviour in pastoral sites: evidence from Famorca, Alacant Province, Spain. Journal of Mediterranean Archaeology, 11(1), 31-52.

Cruz Berrocal, M. (2004). La investigación del arte rupestre desde la geografía: la pintura neolítica del ámbito mediterráneo de la Península Ibérica. Trabajos de Prehistoria, 61(2), 41-62. 
Cruz Berrocal, M. (2005). Paisaje y arte rupestre. Patrones de localización de la pintura levantina. Oxford: BAR S1409.

Cruz Berrocal, M., \& Vicent, J. (2007). Rock art as an archaeological and social indicator: the neolithisation of the Iberian Peninsula. Journal of Anthropological Archaeology, 26, 676-697.

Davidson, I. (1980). Transhumance, Spain and ethnoarchaeology. Antiquity, 54, 144-147.

Davidson, I. (1989). La economía del final del paleolítico en la España oriental. Serie de Trabajos Varios del SIP 85. Valencia: Diputación Provincial de Valencia.

Davis, B. S. A. (1994). Palaeolimnology and Holocene environmental change from Endoreic lakes in the Ebro Basin, North-East Spain. Ph.D. Thesis. Newcastle: University of Newcastle Upon Tyne.

Davis, G. W., \& Richardson, D. (Eds.). (1995). Mediterranean-type ecosystems. The function of biodiversity. Berlin: Springer.

Davis, G. W., \& Rutherford, M. C. (1995). Ecosystem function of biodiversity: can we learn from the collective experience of MTE research? In G. W. Davis \& D. M. Richardson (Eds.), Mediterraneantype ecosystems. The function of biodiversity (pp. 335-350). Ecological Studies 109. Berlin: Springer.

Díaz, J. R. (1984). Geografia y agricultura. Componentes de los espacios agrarios. Madrid: Cincel.

de Vries, B., Thompson, M., \& Wirtz, K. (2002). Understanding: fragments of a unifying perspective. In B. L. de Vries \& J. Goudsblom (Eds.), Mappae Mundi: humans and their habitats in a long-term socioecological perspective (pp. 257-300). Amsterdam: Amsterdam University Press.

Diekmann, L., Panich, L., \& Striplen, CH. (2007). Native American management and the legacy of working landscapes in California. Western landscapes were working long before Europeans arrived. Rangelands, 46-50.

Dupré, M. (1988). Palinología y paleoambiente. Nuevos datos españoles. Serie de Trabajos Varios del SIP 84. Valencia: Diputación Provincial de Valencia.

Ejarque, A., \& Orengo, H. (2009). Legacies of change: the shaping of cultural landscapes in a marginal Mediterranean Mountain Range, the Garraf Massif, North-Eastern Spain. Oxford Journal of Archaeology, 28(4), 425-440.

Ejarque, A., Miras, Y., Riera, A., Palet, J. M., \& Orengo, H. A. (2010). Testing micro-regional variability in the Holocene shaping of high mountain cultural landscapes: a palaeoenvironmental case-study in the eastern Pyrenees. Journal of Archaeological Science, 37, 1468-1479.

Fairén, S. (2006). El paisaje de la neolitización. Alicante: Universidad de Alicante.

Fairén, S., Cruz Berrocal, M., López-Romero González De La Aleja, E., \& Walid Sbeinati, S. (2006). Las vías pecuarias como elementos arqueológicos. In I. Grau Mira (Ed.), La aplicación de los SIG en la arqueología del paisaje (pp. 55-68). Alicante: Universidad de Alicante.

Farnós, A., Arasa, J., Argudo, J. L., Gargallo, E., Porres, A., Querol, J. V., \& Virgili, J. (1993). GúdarMaestrazgo. Madrid: Cuadernos de la Trashumancia 14, ICONA.

Fernández Temprado, C., Farnós, I., Brel, A., Obiol Menero, E., Rodríguez García, M., Virgili Guardia, J., \& Arasa Centelles, J. (1996). Mediterráneo. Madrid: Cuadernos de la Trashumancia 19, Organismo Autónomo Parques Nacionales.

Fernández-Freire, C., \& Uriarte, A. (2011). Modelización del paisaje mediante SIG para la investigación de sociedades agrarias paleotécnicas. In V. Mayoral \& S. Celestino (Eds.), Tecnologías de Información Geográfica y Análisis Arqueológico del Territorio. Actas del V Simposio Internacional de Arqueología de Mérida (pp. 449-458). Mérida: Junta de Extremadura-Consorcio de Mérida.

García-Ruiz, J. M. (2010). The effects of land uses on soil erosion in Spain: a review. Catena, 81(1), 1-11. Gilman, A., \& Thornes, J. B. (1985). Land-use and prehistory in south-east Spain. London: Allen \& Unwin.

Gil-Romera, G., López Merino, L., Carrión, J. S., González-Sampériz, P., Martín-Puertas, C., López Sáez, J. A., Fernández, S., García Antón, M., \& Stefanova, V. (2010). Interpreting resilience through longterm ecology: potential insights in Western Mediterranean landscapes. The Open Ecology Journal, $3,43-53$.

Gómez, A., \& Esteban, A. (1993). Análisis polínico de la turbera de La Feixa (La Màniga, Cerdanya, 2.150 m). Evolución del paisaje. In M. P. Fumanal \& J. Bernabeu (Eds.), Estudios sobre Cuaternario, medios sedimentarios, cambios ambientales, hábitat humano (pp. 185-190). València: Universitat de València.

Gómez-Miguel, V. (2006). Mapa de Suelos de España 1:1.000.000. Madrid: Instituto Geográfico Nacional. González-Hidalgo, J. C., Peña-Monné, J. L., \& De Luis, M. (2007). A review of daily soil erosion in Western Mediterranean areas. Catena, 71, 193-199.

González-Sampériz, P. (2004). Evolución paleoambiental del sector central de la cuenca del Ebro durante el Pleistoceno superior y Holoceno. Zaragoza: Instituto Pirenaico de Ecología-CSIC.

González-Sampériz, P., Valero-Garcés, B. L., Moreno, A., Jalut, G., García-Ruiz, J. M., Martí-Bono, C., Delgado-Huertas, A., Navas, A., Otto, T., \& Dedoubat, J. J. (2006). Climate variability in the Spanish Pyrenees during the last 30,000 yr revealed by the El Portalet sequence. Quaternary Research, 66, 38-52. 
González-Sampériz, P., Valero-Garcés, B. L., Moreno, A., Morellón, M., Navas, A., Machín, J., \& Delgado-Huertas, A. (2008). Vegetation changes and Hydrological fluctuations in the Central Ebro Basin (NE Spain) since the Lateglacial: saline lake records. Palaeogeography, Palaeoclimatology, Palaeoecology, 259, 157-181.

Hernández, M., \& Segura, J. (Coords.) (2002). La Sarga. Arte rupestre y territorio. Alcoy: Ayuntamiento and CAM.

Hernández, M., Ferrer, P., \& Català, E. (1998). L'art llevantí. Cocentaina: Centre d'Estudis Contestans.

Hobbs, R. J., Richardson, D. M., \& Davis, G. W. (1995). Mediterranean-type ecosystems: opportunities and constraints for studying the function of biodiversity. In G. W. Davis \& D. M. Richardson (Eds.), Mediterranean-type ecosystems. The function of biodiversity (pp. 1-42). Ecological Studies 109 (pp. 1-42). Berlin: Springer.

Horden, P., \& Purcell, N. (2000). The corrupting sea. A study of Mediterranean history. Oxford: Blackwell.

Jalut, G., Esteban, A., Riera Mora, I., Mora, S., Fontugne, M., Mook, R., Bonnet, L., \& Gauquelin, T. (1997). Holocene climatic changes in the western Mediterranean: installation of the Mediterranean climate. Comptes Rendus de l'Academie de Sciences de Paris, Sciences de la Terre et des Planètes, 325, 327-334.

Jalut, G., Esteban Amat, A., Bonnet, L., Gauquelin, T., \& Fontugne, M. (2000). Holocene climatic changes in Western Mediterranean, from south-east France to south-east Spain. Palaeogeography, Palaeoclimatology, Palaeoecology, 160, 255-290.

Jarvis, A., Reuter, H.I., Nelson, I., \& Guevara, E. (2008). Hole-filled seamless SRTM data V4. International Centre for Tropical Agriculture (CIAT). http://srtm.csi.cgiar.org

Klein, J. (1990). La Mesta: estudio de la historia económica española, 1273-1836. Madrid: Alianza Editorial.

Lasanta, T. (1987). Cambios en la organización espacial de los usos agrarios del suelo en el Pirineo Central. Anales del Instituto de Estudios Agropecuarios, 9, 103-118.

López Sáez, J. A., López-Merino, L., Alba Sánchez, F., \& Pérez Díaz, S. (2009). Contribución paleoambiental al estudio de la trashumancia en el sector abulense de la Sierra de Gredos. Hispania. Revista Española de Historia, 231, 9-38.

López-García, P. (1992). Análisis polínicos de cuatro yacimientos arqueológicos situados en el Bajo Aragón. In Aragón / Litoral Mediterráneo. Intercambios culturales durante la Prehistoria (pp. 235242). Zaragoza: Institución Fernando el Católico. Universidad de Zaragoza.

López-García, P., \& López-Sáez, J. A. (2000). Le paysage et la phase Épipaléolithique-Mésolithique dans les Pré-Pyrénées Aragonaises et le Bassin Moyen de l'Èbre à partir de l'analyse palynologique. In Les derniers chasseurs-cueilleurs d'Europe occidentale, Actes du colloque international de Besançon, octobre 1998 (pp. 59-69). Besançon: Annales Littéraires 699, Série Environnement, sociétés et archéologie, 1, Presses Universitaires Franc-Comtoises.

López-García, P., López-Sáez, J. A., \& Sánchez, J. (1991). Análisis polínico del yacimiento de Botiquería (Mazaleón, Teruel). Trabajos de Prehistoria, 48, 395-403.

López-Sáez, J. A., \& López-García, P. (1999). Rasgos paleoambientales de la transición TardiglaciarHoloceno (16-7.5 Ka BP) en el Mediterráneo ibérico, de Levante a Andalucía. In Geoarqueologia i Quaternari litoral. Memorial M.P. Fumanal (pp. 139-152). València: Departament de Geografia, Universitat de València.

López-Sáez, J. A., López-García, P., \& Burjachs, F. (2003). Arqueopalinología: Síntesis Crítica. Polen, 12, 5-35.

López-Sáez, J. A., López García, P., \& López Merino, L. (2006). La transición Mesolítico-Neolítico en el Valle Medio del Ebro y en el Prepirineo aragonés desde una perspectiva paleoambiental: dinámica de la antropización y origen de la agricultura. Revista Iberoamericana de Historia, 1, 4-11.

López-Sáez, J. A., López Merino, L., Pérez Díaz, S., \& Alba Sánchez, F. (2011). Paleopaisajes de Andalucía Oriental durante la transición Mesolítico-Neolítico antiguo. In J. F. Gibaja \& A. F. Carvalho (Eds.), Os últimos caçadores-recolectores e as primeiras comunidades produtoras do sul da Península Ibérica e do norte de Marrocos. Promontoria Monográfica 15 (pp. 213-220). Faro: Universidade do Algarve.

Mangas, J. M. (1992). Vias pecuarias. Madrid: Cuadernos de la Trashumancia 0, ICONA.

Martínez, J. (1998). Abrigos y accidentes geográficos como categorías de análisis en el paisaje de la pintura rupestre esquemática. El sudeste como marco. Arqueología Espacial, 19-20, 543-561.

Martínez, J. (2000). La pintura rupestre esquemàtica com a estratègia simbòlica d'ocupació territorial. Cota Zero, 16, 35-46.

Martínez Valle, R., \& Villaverde, V. (Coords.) (2002). La Cova dels Cavalls en el Barranc de la Valltorta. Tirig: Museu de la Valltorta.

Martínez I, Rubio T. (2010). Evolució i pautes de localització de l'art rupestre postpaleolític a Millares i el seu entorn geográfic comarcal. Aproximació al territori des de l'art. Valencia: Universitat de València (unpublished $\mathrm{PhD}$ ). 
Mientjes, A. C. (2004). Modern pastoral landscapes on the island of Sardinia (Italy). Recent pastoral practices in local versus macro-economic and macro-political contexts. Archaeological Dialogues, 10(2), 161-190.

Miras, Y., Ejarque, A., Riera, S., Palet, J. M., Orengo, H., \& Euba, I. (2007). Dynamique holoce'ne de la ve'ge'tation et occupation des Pyrénées andorranes depuis le Néolithique ancien, d'après l'analyse pollinique de la tourbière de Bosc dels Estanyons (2180 m, Vall del Madrid, Andorra). Comptes Rendus Palevol, 6, 291-300.

Miras, Y., Ejarque, A., Orengo, H., Mora, S. R., Palet, J. M., \& Poiraud, A. (2010). Prehistoric impact on landscape and vegetation at high altitudes: an integrated palaeoecological and archaeological approach in the eastern Pyrenees (Perafita valley, Andorra). Plant Biosystems - An International Journal Dealing with all Aspects of Plant Biology, 144(4), 924-939.

Montserrat, J. (1992). Evolución glaciar y postglaciar del clima y la vegetación en la vertiene sur del Pirineo: Estudio palinológico. Monografias del Instituto Pirenaico de Ecología, 6. Zaragoza: Instituto Pirenaico de Ecología, CSIC.

Montserrat, J., \& Vilaplana, J. M. (1987). The paleoclimatic records of the Upper Pleistocene and Holocene in the Llauset Valley (Central Southern Pyrenees). Pirineos, 129, 107-113.

Naveh, Z. (1998). From biodiversity to ecodiversity. Holistic conservation of the biological and cultural diversity of Mediterranean landscapes. In P. Rundel, G. Montenegro, \& F. Jaksic (Eds.), Landscape disturbance and biodiversity in Mediterranean-type ecosystems (pp. 23-53). Ecological studies 136. Berlin: Springer.

Ninyerola, M., Pons, X., \& Roure, J. M. (2005). Atlas Climático Digital de la Península Ibérica. Metodología y aplicaciones en bioclimatología y geobotánica. Bellaterra: Universidad Autónoma de Barcelona.

Pallaruelo, S. (1993). Pirineo aragonés. Madrid: Cuadernos de la Trashumancia 6, ICONA.

Pèlachs, A., Soriano, J. M., Nadal, J., \& Esteban, A. (2007). Holocene environmental history and human impact in the Pyrenees. Contributions to Science, 3(3), 421-429.

Pérez-Obiol, R., Bal, M. C., Pèlachs, A., Cunill, R., \& Soriano, J. M. (2012). Vegetation dynamics and anthropogenically forced changes in the Estanilles peat bog (southern Pyrenees) during the last seven millennia. Vegetation History and Archaeobotany, 21, 385-396.

Prescott, C. (1995). Aspects of early pastoralism in Sogn, Norway. Acta Archaeologica, 66, 163-190.

Redman, C. L., James, S. R., Fish, P. R., \& Rogers, J. D. (2004). Introduction. Human impacts on past environments. In C. L. Redman, S. R. James, P. R. Fish, \& J. D. Rogers (Eds.), The archaeology of global change. The impact of humans on their environment (pp. 1-8). Washington: Smithsonian Institution.

Riera, S. (1996). Incendis i pertorbacions forestals d'origen antròpic durant el Neolític antic al Pla de Barcelona (sector central de la costa catalana). I Congrés del Neolític a la Península Ibérica. GavàBellaterra, 1995. Rubricatum, 1(1), 35-42.

Riera, S., Lopez-Saez, J. A., \& Argilagos, J. B. (2004). Premières traces d'anthropisation à l'est de la Péninsule Ibérique et les Îles Baléares. In H. Richard (dir.), Néolithisation précoce. Premières traces d'anthropisation du couvert végétal à partir des données polliniques (pp. 195-220). Besançon: Annales Littéraires, 777, Série Environnement, sociétés et archéologie, 7, Presses Universitaires Franc-Comtoises.

Ripoll, E. (1962). Representación de un jinete en las pinturas rupestres del Cingle de la Gasulla (Castellón) (pp. 91-93). XIII: Zephyrus.

Ripoll, E. (1968). Cuestiones en torno a la cronología del arte rupestre postpaleolítico en la Península Ibérica. Simposio Internacional de Arte Rupestre (Barcelona 1966) (pp. 165-192). Barcelona: Instituto de Prehistoria y Arqueología. Diputación Provincial de Barcelona.

Rivas Martínez, S. (1982). Étages bioclimatiques, secteurs chorologiques et series de vegetation de 1' Espagne méditerranéenne. Ecología Mediterránea, VIII(172), 275-288.

Rivas Martínez, S. (1987). Memoria del Mapa de Series de Vegetación de España 1:400.000. Madrid: Ministerio de Agricultura, Pesca y Alimentación.

Robb, J. (2007). The early Mediterranean village. Cambridge: Cambridge University Press.

Roigé Ventura, X., Contreras, J., Cots, P., Font, J., Gómez, M. P., Parès, P. M., Peret, M., Ros, I., \& Such, X. (1993). Pirineo catalán. Madrid: Cuadernos de la Trashumancia 13, ICONA.

Rubio de Lucas, J. L., Muñoz Municio, M. C., San José Gómez, S., \& Albert Gamboa, M. J. (1993a). Alcaraz, Cazorla y Segura. Madrid: Cuadernos de la Trashumancia 10, ICONA.

Rubio de Lucas, J. L., Muñoz Municio, M. C., San José Gómez, S., \& Albert Gamboa, M. J. (1993b). Sierra Morena Oriental. Madrid: Cuadernos de la Trashumancia 7, ICONA.

Ruiz, J. (2006). Las pinturas rupestres en la Serranía de Cuenca. Análisis, revisión y crítica del concepto de estilo en las manifestaciones plásticas postpaleolíticas. Madrid: Facultad de Geografía e Historia. UNED (unpublished $\mathrm{PhD}$ ).

Ruiz Gálvez, M. L. (2002). Hallarse en la encrucijada. El área levantina, entre Oriente y Occidente. In ...y acumularon tesoros. Mil años de historia en nuestras tierras (pp. 137-150). Elche: CAM. 
Ruiz, J., Mas, M., Hernanz, A., Gavira, J. M., Rowe, M., \& Steelman, K. (2006). First Radiocarbon dating of Oxalate Crusts over Spanish Prehistoric Rock Art. Inora Newsletter, 46.

Rundel, P. (1998). Landscape disturbance in Mediterranean-type ecosystems: an overview. In P. Rundel, G. Montenegro, \& F. Jaksic (Eds.), Landscape disturbance and biodiversity in Mediterranean-type ecosystems (pp. 3-22). Ecological studies 136. Berlin: Springer.

Rundel, P., Montenegro, G., \& Jaksic, F. (Eds.). (1998). Landscape disturbance and biodiversity in Mediterranean-type ecosystems. Berlin: Springer.

Sánchez Moreno, E. (1998). De ganados, movimientos y contactos. Revisando la cuestión trashumante en la Protohistoria hispana: la meseta occidental. Studia Historica. Historia Antigua, 16, 53-84.

Sánchez-Goñi, M. F., \& Hannon, G. (1999). High-altitude vegetational pattern on the Iberian Mountain Chain (north-central Spain) during the Holocene. The Holocene, 9, 39-57.

Sebastián López, M. (2011). Geografia del Arte Rupestre: herramientas espaciales y TIG para el análisis territorial del arte rupestre levantino y esquemático en Aragón. Zaragoza: Universidad de Zaragoza (unpublished PhD).

Shiel, R. S. (1999). Reconstructing past soil environments in the Mediterranean region. In P. Leveau, F. Trément, K. Walsh, \& G. Barker (Eds.), Environmental reconstruction in Mediterranean landscape archaeology (pp. 67-79). Oxford: The Archaeology of Mediterranean Landscapes 2, Oxbow Books.

SOIL SURVEY GROUP (2003). Keys to soil taxonomy. United States Department of Agriculture.

Soria, M., \& López, M. (1999). Los abrigos con arte rupestre levantino de la Sierra de Segura. Sevilla: Arqueología Monografías, Junta de Andalucía.

Stevenson, A. C. (2000). The Holocene forest history of the Montes Universales, Teruel, Spain. The Holocene, 10, 603-610.

Utrilla, P. (2005). El arte rupestre en Aragón. 100 años después de Calapatá. In M. Hernández \& J. Soler (Eds.), Actas del Congreso de Arte rupestre en la España Mediterránea (Alicante, 2004) (pp 341-378). Instituto Alicantino de Cultura Juan Gil-Albert y Caja de Ahorros del Mediterráneo: Alicante.

Utrilla, P., \& Bea, M. (2011). Las cerámicas del Plano del Pulido (Caspe). Sagvntvm, 12, 147-153.

Utrilla, P., Bea, M., \& Benedí, S. (2010). Hacia el Lejano Oeste. Arte levantino en el acceso a la Meseta: la Roca Benedí (Jaraba, Zaragoza). Trabajos de Prehistoria, 67(1), 227-243.

van Andel, T. H., Zangger, E., \& Demitrack, A. (1990). Land use and soil erosion in prehistoric and historical Greece. Journal of Field Archaeology, 17, 379-396.

van der Leeuw, S., \& de Vries, B. L. (2002). Empire: the Romans in the Mediterranean. In B. L. de Vries \& J. Goudsblom (Eds.), Mappae Mundi: Humans and their habitats in a long-term socio-ecological perspective (pp. 209-256). Amsterdam: Amsterdam University Press.

Vicent, J. M. (1991). Fundamentos teórico-metodológicos para un programa de investigación arqueo-geográfica. In P. López (Ed.), El cambio cultural del IV al II milenios a.C. en la comarca noroeste de Murcia (pp. 29-117). Madrid: CSIC.

Vita-Finzi, C. (1969). The Mediterranean valleys: geological changes in historical times. Cambridge: Cambridge University Press.

Walsh, K. (1999). Mediterranean landscape archaeology and environmental reconstruction. In P. Leveau, F. Trément, K. Walsh, \& G. Barker (Eds.), Environmental reconstruction in Mediterranean landscape archaeology (pp. 1-8). Oxford: The Archaeology of Mediterranean Landscapes 2, Oxbow Books. 